\title{
34. THE FORAMINIFER RECORD AT SITE 847: PALEOCEANOGRAPHIC RESPONSE TO LATE PLEISTOCENE CLIMATE VARIABILITY ${ }^{1}$
}

\author{
V.S. McKenna, ${ }^{2}$ J.W. Farrell, ${ }^{3}$ D.W. Murray, ${ }^{2}$ and S.C. Clemens ${ }^{2}$
}

\begin{abstract}
Sediments from Site 847 in the eastern equatorial Pacific Ocean provide a record of the variability of the equatorial divergence and associated upwelling. We interpret the variation in foraminifer assemblages in the context of regional oceanographic change. Our record is composed of three time slices selected from the last $0.9 \mathrm{Ma}$. AQ-mode analysis of foraminifer abundance data results in a four-factor model that was used to quantify the faunal changes and to characterize paleoceanographic variability. The species of foraminifers with high factor scores for each factor suggested a specific set of oceanographic conditions. The timing of the high loadings for each factor appears to be associated with a particular part of a glacial cycle. Thus, we interpreted our findings in the context of the glacial/interglacial cycle proposed by Imbrie et. al. (1992). This idealized cycle consists of four stages that are defined by characteristic changes in specific elements of the climate system. We evaluated how such changes in the climate system might affect the oceanographic conditions at Site 847.

Our results suggest that upwelling remains a dominant process in both glacial and interglacial stages, but decreases significantly on most deglacials. Subantarctic mode water formation and equatorial upwelling appear to form a linked system that determines the specific characteristics of the water forming a major part of the Equatorial Undercurrent as well as the transport volume of the undercurrent. In conjunction with changes in upwelling at Site 847, this variation in the undercurrent results in changes in mixed layer depth, sea-surface temperature, and oxygen and nutrient levels at the site.
\end{abstract}

\section{INTRODUCTION}

The tropical regions of the world ocean are important sites for interaction between the atmosphere and the ocean. Ocean Drilling Program (ODP) Leg 138, in the eastern tropical Pacific Ocean, was designed as part of a series of research initiatives that had already provided transects from the equatorial Atlantic Ocean (Leg 108), western, equatorial Pacific Ocean (Legs 85 and 130), and low-latitude Indian Ocean (Legs 115 and 117). A major goal of Leg 138 was to obtain high-resolution cores that would supply information about global climate during the Neogene (Shipboard Scientific Party, 1992).

Site $847\left(0^{\circ} 12^{\prime} \mathrm{N}, 95^{\circ} 19^{\prime} \mathrm{W} ; 3334 \mathrm{~m}\right.$ water depth), west of the Galapagos Islands, is located beneath the core of the South Equatorial Current and under the equatorial divergence (Fig. 1). Reconstruction of Nazca Plate motion indicates that Site 847 has moved eastward through time, while remaining at its present latitude throughout (Shipboard Scientific Party, 1992). Therefore, the sedimentary record at Site 847 was to provide information about late Neogene paleoceanographic variation of the equatorial divergence. Data from this and the other sites that comprise Leg 138 were expected to contribute to a historical reconstruction of the eastern equatorial Pacific Ocean current system and to lead to greater understanding of the global climate system (Shipboard Scientific Party, 1992).

Site 847 yielded a continuous record of sedimentation based on multiple offset holes. The sediments recovered at Site 847 primarily consist of nannofossil ooze and diatom nannofossil ooze. An initial assessment indicated that planktonic foraminifers are common to abundant and at least moderately well preserved in those sections of the core representing the upper Pleistocene sequence (Shipboard Scientific Party, 1992).

I Pisias, N.G. Mayer, L.A. Janecek, T.R., Palmer-Julson, A., and van Andel, T.H (Eds.). 1995. Proc: ODP Sci. Results, 138: College Station TX (Ocean Drilling Program), U.S.A.

Department of Geological Sciences, Brown University, Providence, RI 02912-1846,

${ }^{3}$ Department of Geological Sciences, Brown University, Providence, RI 02912-1846, U.S.A. (now at Department of Oceanography, University of British Columbia, Vancouver, V6T 1Z4, B.C., Canada).
Because each species of planktonic foraminifer requires varying combinations of environmental conditions for growth, the species assemblage present in sediment can provide important information about the environmental variables characterizing the water in which they lived. Also, the foraminifer tests record chemical and isotopic information from the extant seawater. The preservation state of the tests monitors changing chemical conditions at both the sediment/ water interface and in the pore waters. This study documents variation in the relative abundances of planktonic foraminifers and assesses the effects of dissolution on the foraminiferal assemblages at three time slices during the Pleistocene. Variability in the records of faunal assemblages provides insight into changes in the Equatorial Undercurrent and upper water column structure in response to mode water formation at high latitudes.

\section{OCEANOGRAPHIC SETTING}

In the equatorial current system of the eastern Pacific, westward surface transport occurs in the North and South Equatorial Currents (NEC and SEC, respectively) (Fig. 1). These two currents are separated by and partially fed from the North Equatorial Countercurrent (NECC), which transports surface water to the east. Additional eastward transport occurs in the subsurface Equatorial Undercurrent (EUC). Because the tradewind belt is asymmetrical with respect to the equator, the strength of the two northern components of the equatorial current system, the NEC and the NECC, respond to the position of the trade wind belt, rather than to the strength of the winds (Fig. 2) (Wyrtki, 1974a). From January through April, the tradewind belt is at its most southerly position, the northeast trades are at their peak strength, and the NEC and the NECC are weakest. The location of maximum wind strength is far south of the NEC, and the trade winds oppose transport in the NECC. From September through November, the wind system is located at its maximum northerly position, the northeast tradewinds are at minimum strength, and the NEC and the NECC are strongest. Conversely, the SEC, east of $140^{\circ} \mathrm{W}$, and the EUC are strongest when the southeast tradewinds are at their peak strength from September through November, with the wind system at its most northerly position (Wyrtki, 1974a, 1974b). 


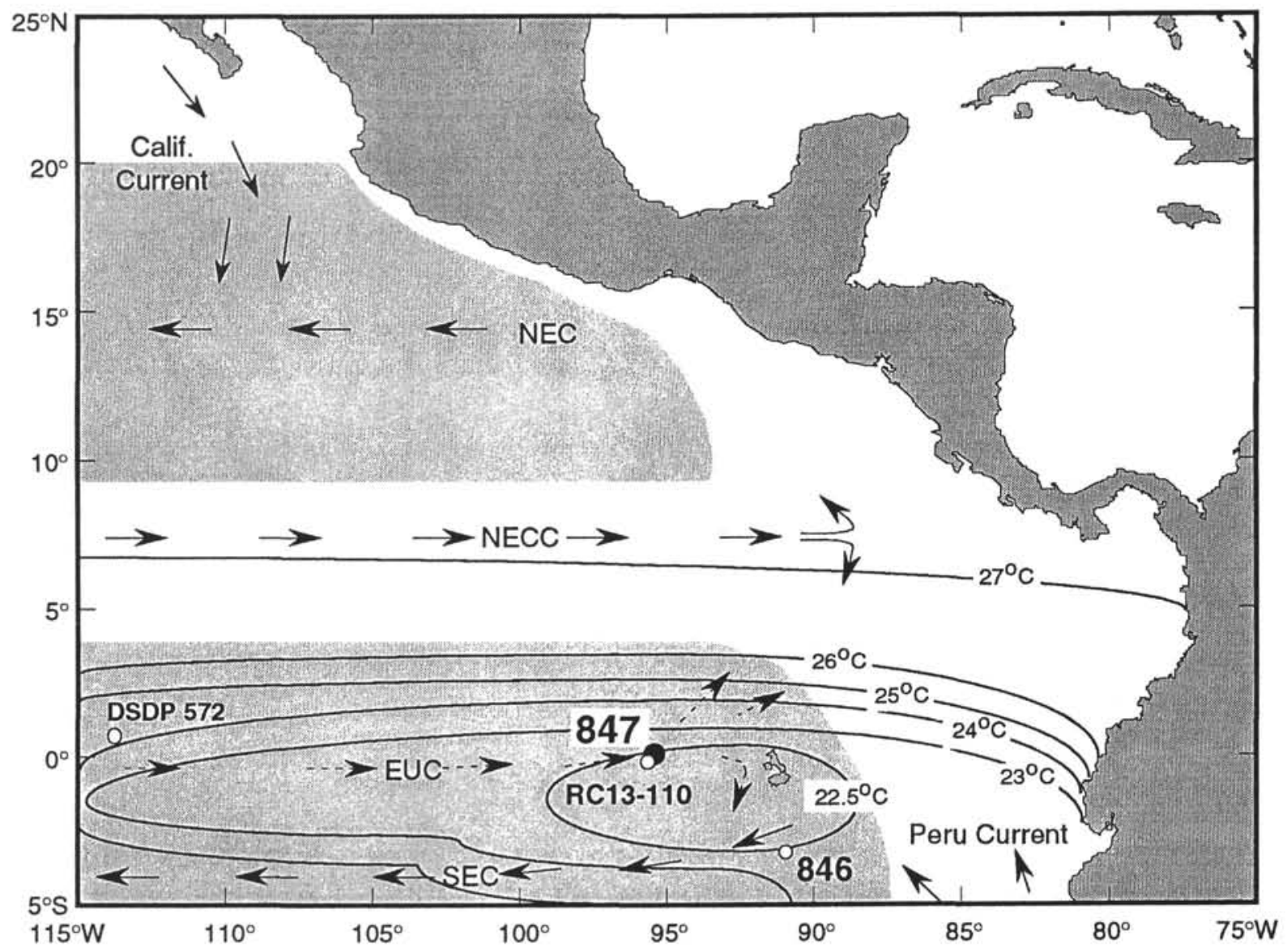

Figure 1. Site 847 (closed circles) is located within the region of divergence defined by the major regional current system. Solid arrows represent surface currents; dashed arrows represent subsurface currents. The locations of piston core RC13-110, DSDP Site 572, and ODP Site 846 (cores referred to in the text) are also shown (open circles). Isotherms for the region are also shown.

The NEC and SEC are extensions of the California and Peru currents, which transport cold water from higher latitudes (Wyrtki, 1966). The Peru Current (PC) is associated with coastal upwelling, the influence of which extends into the region east of the Galapagos Islands. In addition, the equatorial divergence creates a larger region of upwelling to the west of the Galapagos Islands (Pak and Zaneveld, 1974). The EUC shallows in response to this upwelling, and the differences in the physical properties between the water of the undercurrent and the surface water create strong gradients in oceanographic parameters at the edges of the upwelling zone (Pak and Zaneveld, 1974; Wyrtki, 1981; Bryden and Brady, 1985). Both the path of the undercurrent and the location of upwelling are constrained by the change in the sign of the Coriolis Effect at the equator. Site 847 is located in the regional tongue of cool water at the point where the coldest water of the EUC reaches the surface (Pak and Zaneveld, 1974).

The water transported by the EUC is not homogeneous and can be divided into two broad categories (Tsuchiya et al., 1990). The core of the undercurrent is defined as that water having the highest velocity $(120-150 \mathrm{~cm} / \mathrm{s}$ ) and is located in the pycnocline (Wyrtki, 1966). The source water for this portion of the current originates in the central South Pacific and the low-latitude eastern South Pacific (Tsuchiya et al., 1990). The water from this first category will be called the upper layer core water in subsequent references. The second category of water has been called Equatorial $13^{\circ}$ Water (Montgomery and Stroup, 1962) and is composed of water in the subpycnocline that is colder, slightly less saline, better oxygenated, and with higher levels of nutrients than the water in the core of the undercurrent. Based on observed low ${ }^{14} \mathrm{C}$ values in the equatorial Pacific and the geographic distribution of pre-bomb ${ }^{14} \mathrm{C}$ values, Toggweiler et al. (1991) sug- gested that this water originates as the lighter Subantarctic Mode Water of McCartney (1982). The water from this category will be called the lower layer mode water in subsequent references. If the EUC's total transport is divided into uniform density classes, this lower layer mode water accounts for the largest flux because of its homogeneity and thickness (Tsuchiya et al., 1990). Upwelling extends down to approximately $180 \mathrm{~m}$, although the vertical velocity is zero at this depth (Bryden and Brady, 1985). In practice, maximum upwelling extends from about 40 to $100 \mathrm{~m}$. Therefore, as the EUC shallows toward the east, upwelling involves increasing amounts of the lower layer mode water.

The EUC supplies, at subsurface, most of the water of the SEC. This transport is supplemented by water from the PC and the NECC, which accounts for the total transport of the SEC (Wyrtki, 1966). In addition, the EUC ventilates the thermocline, contributes to Peru coastal upwelling, and partially feeds the Peru Countercurrent (Wyrtki, 1966; Toggweiler et al., 1991).

\section{SAMPLING METHODS AND RESEARCH STRATEGY}

\section{Composite Depth}

The construction of a continuous sedimentary section is the basis for the interpretation of paleoceanographic and climatic time series. A composite depth section (Bmcd) was constructed from four offset holes at Site 847 , providing a continuous stratigraphic sequence for the site. The strategy used to construct this composite is similar to the approach in the shipboard work (see Hagelberg et al., 1992, and Shipboard Scientific Party, 1992, table 7), except that Hole 847C was 
used as the primary stratigraphic signal and section from Holes 847B and $847 \mathrm{D}$ were used to fill in gaps at core breaks. The construction of the Site 847 composite is documented in Farrell et al. (this volume) and Murray et al. (this volume).

\section{Age Model}

An age model for the top $29 \mathrm{~m}$ of Site 847 was developed by Farrell et al. (this volume) based on the visual correlation of the Site 847 oxygen isotope record to the SPECMAP stacked record of Imbrie et al. (1984) from 0 to $0.631 \mathrm{Ma}$ and of that of Shackleton et al. (1990) from 0.631 to $1.143 \mathrm{Ma}$. The oxygen isotope data for Site 847 were measured from specimens of Globigerinoides sacculifer from the 300 - to $350-\mu \mathrm{m}$ size fraction and from Neogloboquadrina dutertrei from the $355-$ to $425-\mu \mathrm{m}$ fraction in the Benedum Stable Isotope Laboratory at Brown University (Farrell et al., this volume). Farrel et al. (this volume) discusses the difference between this isotope chronostratigraphy and an age model of Shackleton et al. (this volume) based on correlation of GRAPE maxima to Northern Hemisphere insolation maxima.

\section{Research Strategy}

Our intent in this study was to examine the late Pleistocene orbitalscale variations in eastern Pacific Ocean circulation as recorded by foraminifers. Within the time frame of this post-cruise study, a continuous time series from multiple sites was not possible. Site 847 was selected to monitor the oceanographic changes within the Equatorial Undercurrent and complements the study at Site $846\left(3^{\circ} 5.7^{\prime} \mathrm{S}\right.$, $90^{\circ} 49.08^{\prime} \mathrm{W}, 3307 \mathrm{~m}$ depth) in the Peru Current (Le et al., this volume) and DSDP Site $572\left(1^{\circ} 26.09^{\prime} \mathrm{N}, 113^{\circ} 50.52^{\prime} \mathrm{W}, 3903 \mathrm{~m}\right.$ depth) to the west (M.T. Chen, pers. comm., 1994). Our sampling strategy was guided by the knowledge of existing foraminifer data in piston core $\mathrm{RC} 13-110\left(0^{\circ} 6^{\prime} \mathrm{N}, 95^{\circ} 40^{\prime} \mathrm{W}, 3231 \mathrm{~m}\right.$ depth) spanning the past 0.425 Ma (A. Mix, pers. comm., 1992) and by variability in the oxygen isotope gradient between surface and deep dwelling foraminifers (Fig. 3 ; Farrell et al., this volume) that suggests oceanographic changes in the mixed layer.

With these considerations in mind we generated a foraminifer record from Site 847 which consists of three time slices (Fig. 3), rather than a continuous record of the youngest samples. Time Slice 1 (TS1) covers oxygen isotope stages 1 to $6(0-0.135 \mathrm{Ma})$, Time Slice 2 (TS2) covers stages 11 to 14 (0.395-0.572 Ma), and Time Slice 3 (TS3) covers stages 18 to 21 ( $0.704-0.852 \mathrm{Ma})$.

TS1 extends through isotope stage 5 so that we would have a range of climate states over which we could compare our record with the foraminifer data from RC13-110. We began our comparison by computing simple statistics of minimum, maximum, and standard deviation for the foraminifer species in each core. Downcore abundance patterns for those species with the larger relative abundances were plotted and visually examined. We identified two differences in taxonomy resulting from slightly different criteria for distinguishing between (1) Neogloboquadrina dutertrei and P-D intergrade and (2) Globorotalia inflata and Globorotalia scitula. To assess the effects that these taxonomic differences might have upon further statistical analysis, we subjected both data sets to Q-mode factor analysis, compared the resulting factors, and, finally, projected the varimax factor scores from a four-factor model developed from the Site 847 data set onto the data from RC13-110 (see "Statistical Methods" section, below, for descriptions of techniques). In addition, we used the Modern Analog Technique (MAT) to find analogs for the samples of both records from a modified Prell (1985) database. Because each of these analyses produced similar results, we concluded that, with only slight modification for the $G$. inflata/G. scitula differences, the planktonic foraminifer records from Site 847 and RC13-110 can be merged to form a combined record for future work.

We chose the extent of TS2 with two purposes in mind. We wanted the start of this time slice to overlap the end of the data from RC13-

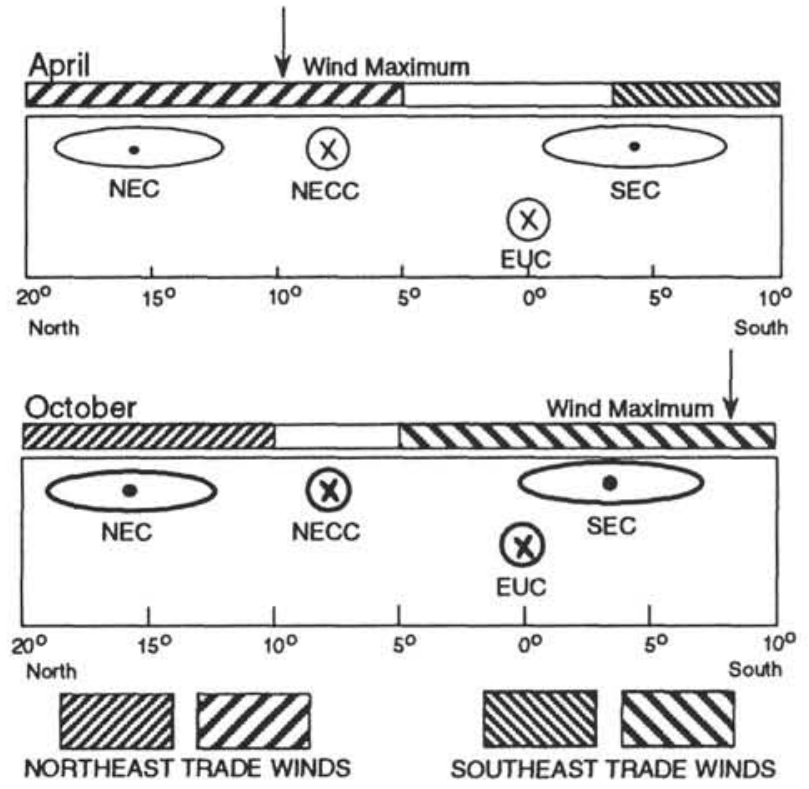

Figure 2. Relation of trade winds and eastern equatorial Pacific Ocean currents, east of $140^{\circ} \mathrm{W}$. Influence zones for the trade winds are indicated by slanted lines. The ocean currents are depicted as either the head or tail end of an arrow, depending on the direction of the flow. The line weights for both the winds and currents represent their relative strength. (Adapted from Wyrtki, 1974a, 1974b.)

110 to ease the possible future development of a combined record. In addition, the Site 847 isotope gradient exhibits a long-term increase beginning at about $0.750 \mathrm{Ma}$ and ending near $0.400 \mathrm{Ma}$. TS2 was designed to cover the younger half of this trend and to include two minima resulting from higher frequency variation imposed on the longer term increase. We chose TS3 to include a high amplitude drop in the isotope gradient between isotope stages 19 and 20. This drop is the predecessor to the lowest values of the isotope gradient and leads into the long term increase. Thus, in conjunction with Farrell et al. (this volume), a combination of isotopic and faunal indicators has been used to help constrain interpretations of paleoceanographic changes. In this paper, we have focused on the implications of variability in the abundances of foraminifer species.

The 89 sediment samples used in this study were each analyzed for foraminifer abundance (this work), carbonate, opal, coarse fraction, and stable isotopes (Farrell et al., this volume; Murray et al., this volume). With an average Pleistocene sedimentation rate of approximately $30 \mathrm{~m} / \mathrm{m} . \mathrm{y}$., the average sample spacing of $15 \mathrm{~cm}$ yields a resolution of about 0.005 m.y.

Processing of the raw sample before faunal analysis has been detailed by Farrell et al. (this volume). Optimally, the foraminifer sample then was randomly split until a subsample having a minimum of 270 whole tests, above $150 \mu \mathrm{m}$, was achieved. In three samples, a large abundance of radiolarians increased the difficulty of achieving a subsample of this size. These remaining samples contained 204 , 255 , and 234 individuals. In the following statistical analyses, these smaller samples did not produce results that differed markedly from adjacent samples. The foraminifer taxonomy used in this study is based on Parker (1962), Bé (1967), and Kipp (1976).

\section{STATISTICAL METHODS}

\section{Dissolution Indexes}

Dissolution of $\mathrm{CaCO}_{3}$ is a process that alters the relative abundances of the foraminifer species in the sediment, because species have varying resistance to dissolution (Berger, 1970, Parker and Berger, 1971; Thompson, 1976). Any analysis based on the species content of a foraminifer assemblage must assess the possible altera- 


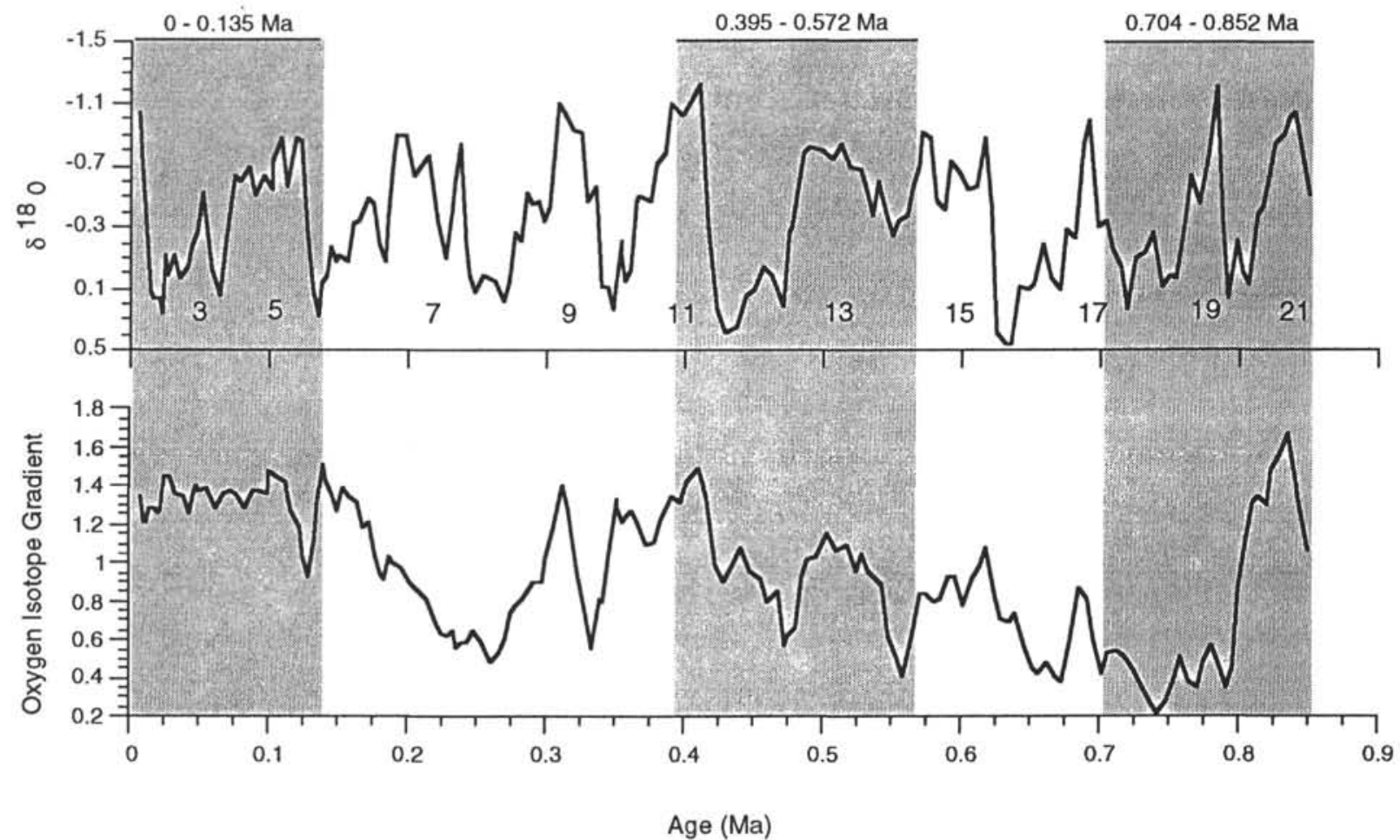

Figure 3. The $\delta^{18} \mathrm{O}$ composite record measured on G. sacculifer is shown in conjunction with the gradient between that record and the $\delta^{18} \mathrm{O}$ record measured on $N$. dutertrei (Farrell and Murray, this volume). The gradient is calculated as the $\delta^{18} \mathrm{O}$ of $N$. dutertrei- $\delta^{18} \mathrm{O}$ of $G$. sacculifer. The faunal record covers the shaded areas topped by black bars, and the exact age range of the samples is provided. See text for an explanation of the experimental strategy.

tion produced by dissolution. With this as a goal, various methods have been developed to quantify the amount of dissolution that has taken place. The calculation methods for indexes used with the data from Site 847 are listed in Table 1. Each of these indexes has its own pattern of response to variation in foraminifer ecology, in overall productivity, and in the depositional environment.

Calculation of $\mathrm{CaCO}_{3}(\%)$ is a common index used to measure the amount of dissolution affecting carbonate sediments. However, direct correlation of $\mathrm{CaCO}_{3}(\%)$ variation to changes in dissolution is complicated, because the index responds to a combination of changes in dissolution, production, and dilution. An additional concern is the nonlinear response of $\mathrm{CaCO}_{3}(\%)$ to dissolution. When $\mathrm{CaCO}_{3}(\%)$ values are high, a seemingly small decrease in the carbonate percentage represents a significant loss of carbonate from the sediment (Broecker and Peng, 1982). This characteristic minimizes the perception of dissolution.

Because, we need an accurate assessment of dissolution when documenting the foraminifer record, other dissolution proxies such as whole planktonic foraminifers (\%), foraminifer flux, coarse fraction (\%), and dissolution-resistant species (\%) (Cullen and Prell, 1984) were used to provide further information on dissolution variation in the three time slices of our record (Table 1). Using these indexes jointly helps identify those portions of the record that respond primarily to environmental conditions other than dissolution.

The coarse fraction $(\%)$ is sensitive to dissolution because the chemical process decreases test strength and leads to fragmentation of foraminifer tests into smaller sized particles, transferring a greater percentage of the sample weight to the $<150-\mu \mathrm{m}$-sized fraction (Peterson and Prell, 1985). Foraminifer flux (foraminifer $/ \mathrm{cm}^{2} \cdot \mathrm{k} . \mathrm{y}$.), which is strongly dependent on the calculated sedimentation rate, is determined by a combination of productivity and dissolution. Although whole planktonic foraminifers $(\%)$ and dissolution-resistant species (\%) are commonly used measures of dissolution, these indexes also will be influenced by variation in the faunal composition of the living assemblage. If dissolution-susceptible species are a major component of the surface population, the sedimentary assemblage will be altered more by dissolution than if the surface population was composed primarily of dissolution-resistant species. However, the two indexes do not respond identically to ecologically caused faunal change. The percentage of dissolution-resistant species is an index based on the division of the foraminifer species into two groups; dissolution resistant and dissolution susceptible. This index is based on the percentage of the dissolution-resistant species relative to the total sample population. This method of calculation yields an index that is more sensitive to changes in the foraminifer ecology than is the percentage of whole planktonic foraminifers. Periods when ecologic factors are more influential than dissolution can be identified when dissolution-resistant species (\%) and whole planktonic foraminifers (\%) are of opposite signs. Such a relationship between these two indexes is evident in specific sections of our time slices.

The dissolution-resistant species (\%) is quite similar to a method proposed by Berger (1973), a Foraminifer Dissolution Index (FDI), in which each species has its own dissolution ranking. Because use of the FDI has the potential to increase the sensitivity of the analysis of dissolution effects, the foraminifer relative abundances and the species dissolution ranking of Berger (1970) were used to calculate a FDI for Site 847 (Appendix). Visual comparison of the downcore records of the FDI and the dissolution-resistant species (\%) indicated that the patterns of variation are very similar. A least-squares regression between the two yields a correlation coefficient of 0.844 . Because these two dissolution indexes produce consistent results, the simpler of the two, resistant species (\%), will be used here.

\section{Q-mode Factor Analysis}

We used Q-mode analysis to group species with correlated abundance patterns into ecologically significant assemblages. This form of eigenvalue analysis produces a set of factor loadings that repre- 
Table 1. Calculation methods for indexes of dissolution.

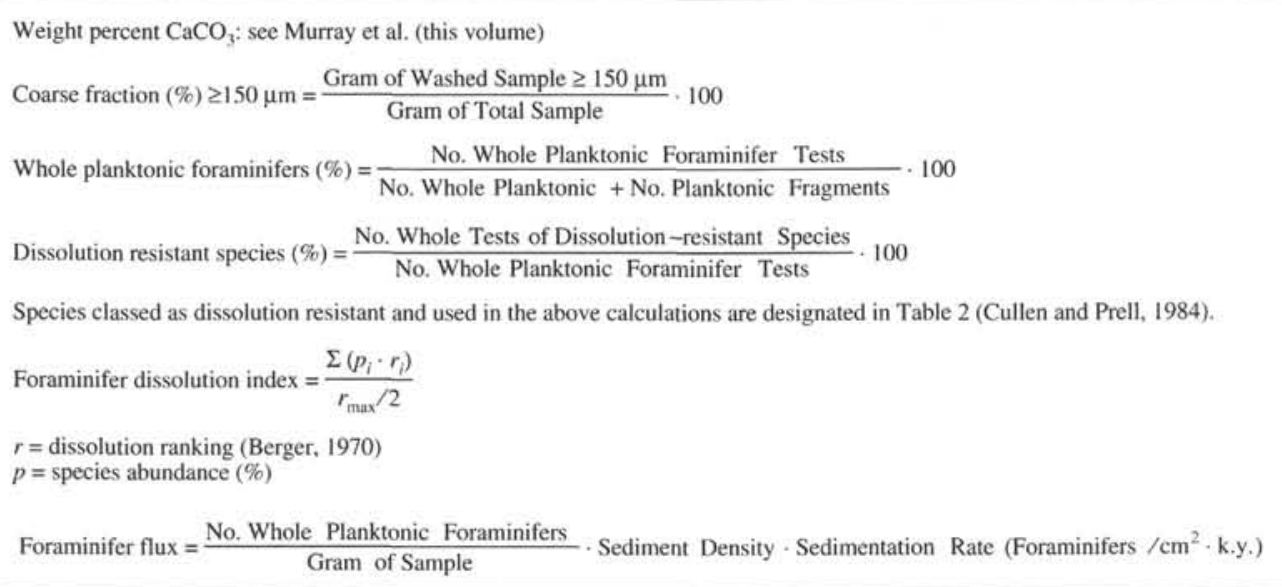

sents uncorrelated end-member samples, with the computed factor scores defining these new end-members in terms of their species components. The association of species with high scores in a particular factor can provide a clearer picture of relevant oceanic processes or environmental conditions affecting the foraminifer assemblage.

A Q-mode factor analysis was performed on the relative abundances of the complete suite of species in the 89 faunal samples using the CABFAC program (Imbrie and Kipp, 1971; Klovan and Imbrie, 1971). Varimax rotation was used to maximize variance on the loadings. Untransformed percent abundance data were used for the calculation, although this does result in $N$. dutertrei having at least a moderately high score in all factors because of the species' high abundance and large standard deviation. However, using a percent range transformation gave too much weight to species with minor abundances, resulting in unrealistic species components for the factors.

\section{Modern Analog Technique}

The Modern Analog Technique (MAT) is an algorithm used to estimate an environmental variable (e.g., sea-surface temperature, SST) associated with a fossil sample. This method has been used with pollen spectra by Prentice (1980) and Overpeck et al. (1985). Subsequently, MAT was applied to foraminifers by Prell (1985) to estimate changes in SST. MAT calculates the dissimilarity between a multivariate fossil sample and a multivariate modern sample contained in a database, compiles a set of most similar analogs, and averages their associated environmental values to calculate a value for the fossil sample. In this study we used the squared chord distance, a signal-to-noise measure, to determine the dissimilarity between the modern and fossil assemblages. Core tops that had a dissimilarity greater than 0.4 were not considered when compiling the list of 10 best analogs for the SST calculation. A modified Prell (1985) database was used in this study. Cores in the original database were inconsistent concerning the division of $N$. pachyderma into left- and right-coiling varieties. The modified database now makes the distinction between coiling directions in all core tops (Pacific data provided to J. Cullen by F. Parker, 1993).

MAT assumes that the values of the species abundances being analyzed are a function of the environmental variable being calculated, that the species were in equilibrium with their environments while living, and that the species response to the environment has been stable throughout time. Taphonomic processes must not alter the abundances to the extent that the fossil assemblages no longer properly represent the living assemblages (Prell, 1985). Because this technique calculates the value for SST from a set of globally distributed core tops, geographic information on the analogs can be used to better understand the paleoceanographic character of the site the time the sample was deposited.

\section{RESULTS}

The results of the foraminiferal analysis (Table 2 and Fig. 4) indicate significant variability through the Pleistocene that exceeds expectations for tropical regions (Moore, 1981). Five species have maximum abundances above the $25 \%$ level, with an additional five species above the $10 \%$ level. Individually, these 10 species have restricted modern geographic distributions that range from tropical to subpolar and polar. This faunal variability suggests dynamic paleoceanographic conditions at Site 847 throughout much of the past $0.90 \mathrm{Ma}$. An examination of the abundance records for individual species and their correlation with dissolution indexes are the first steps toward understanding the oceanographic conditions that produced this faunal record.

\section{Relative Abundance of Foraminifers}

$N$. dutertrei, common in active current systems and upwelling zones (Bé, 1977), is the dominant species for most of the last $0.80 \mathrm{Ma}$ with maximum abundance values near $70 \%$ and a mean of $45 \%$ (Fig. 4). In general, the lowest abundances for this species are on glacial/ interglacial transitions and in glacial stages 2 and 4 . A notable decrease in the relative abundance occurred during isotope stages 18 to 20 .

Globorotalia menardii is the species with the second highest maximum abundance (Fig. 4). Abundances generally were highest during interglacial stages. The higher abundance values during the midBrunhes and lower values at the beginning and end of the Brunhes suggest the existence of a cycle in G.menardii abundance.

Globigerinoides ruber and G. sacculifer have similar abundance patterns. During TS3, the abundances of both species reached their highest values. Although both species are dissolution susceptible, their variation in this time slice correlates well with that of $G$. menardii, a dissolution-resistant species. Although this correlation also was present during stages 5 and 11 , the reduced amplitude of the $G$. ruber and $G$. sacculifer records might be a result of dissolution. $G$. menardii, $G$. ruber, and G. sacculifer are all tropical/subtropical in occurrence.

Globorotalia inflata is a transition species between subtropical and subpolar provinces (Bé, 1977) (Fig. 4). Although the species was completely absent for most of the Pleistocene, its abundance record exhibits a pattern that is characterized by occasional, large spikes of short duration. $G$. inflata was abundant during glacial isotope stages 2,4 , and 18 , during the $18 / 19$ transition, and during interglacial stage 19. Conversely, the species was entirely absent from glacial stages 12 and 14. This pattern of abundance is regional in extent and occurs in cores from the southeast tropical Pacific studied by Luz (1973) and at nearby DSDP Site 572 (Chen, 1994) and Site 846 (Le et al., this volume), and in piston core RC13-110 (A. Mix, pers. comm., 1993). 
Table 2. Statistical summary of each species of foraminifer found at Site 847.

\begin{tabular}{|c|c|c|c|c|c|}
\hline Foraminifer & Code & Minimum & Maximum & Mean & SD \\
\hline Neogloboquadrina dutertrei & N. duter.* & 13.62 & 73.36 & 45.37 & 13.92 \\
\hline Globorotalia menardii & G. menar.* & 0.00 & 30.47 & 7.95 & 6.23 \\
\hline Globorotalia inflata & G. infla.* & 0.00 & 30.00 & 2.44 & 6.52 \\
\hline Globigerina bulloides & G. bullo. & 0.00 & 27.69 & 7.75 & 4.86 \\
\hline Neogloboquadrina pachyderma (L) & N. pac. (L)* & 0.00 & 27.43 & 3.61 & 6.86 \\
\hline Globigerinoides ruber & G. ruber & 0.25 & 16.85 & 5.38 & 3.24 \\
\hline Neogloboquadrina pachyderma (R) & N. pac. $(\mathrm{R})^{*}$ & 0.00 & 16.31 & 5.33 & 3.90 \\
\hline "P-D intergrade" & P-D.int. * & 0.00 & 16.30 & 6.00 & 4.72 \\
\hline Globigerinoides sacculifer & G. sacc. & 0.00 & 12.90 & 3.16 & 2.58 \\
\hline Globigerinita glutinata & G. gluti. & 0.00 & 12.05 & 3.24 & 2.16 \\
\hline Globoquadrina hexagona & G. hexag. & 0.00 & 7.18 & 0.95 & 1.05 \\
\hline Pulleniatina obliquiloculata & P. obliq.* & 0.00 & 6.45 & 0.77 & 0.98 \\
\hline Glogorotalia crassaformis & G. crasf. $*$ & 0.00 & 6.03 & 0.56 & 1.06 \\
\hline Orbulina universa & O. univ & 0.00 & 5.02 & 1.57 & 1.18 \\
\hline Globoratalia tumida & G. tumid.* & 0.00 & 4.24 & 0.71 & 0.71 \\
\hline Globorotalia theyeri & G. theyr. & 0.00 & 3.99 & 0.33 & 0.78 \\
\hline Globorotalia truncatulinoides (R) & G. trunc. (R)* & 0.00 & 3.53 & 0.53 & 0.86 \\
\hline Globigerinella aequilateralis & G. aequi. & 0.00 & 3.01 & 0.70 & 0.61 \\
\hline Globigerina calida & G. calid. & 0.00 & 2.75 & 0.69 & 0.58 \\
\hline Globigerina falconensis & G. falco. & 0.00 & 2.75 & 0.57 & 0.61 \\
\hline Globoquadrina conglomerata & G. cglom. & 0.00 & 1.63 & 0.27 & 0.34 \\
\hline Globigerina digitata & G. digit. & 0.00 & 1.58 & 0.28 & 0.35 \\
\hline Globigerinoides tenellus & G. tenel. & 0.00 & 1.54 & 0.21 & 0.33 \\
\hline Globorotalia scitula & G. scitu. & 0.00 & 1.43 & 0.34 & 0.39 \\
\hline Globigernoides conglobatus & G. cglob. & 0.00 & 1.42 & 0.12 & 0.23 \\
\hline Globigerina rubescens & G. rubes. & 0.00 & 1.38 & 0.28 & 0.37 \\
\hline Globorotalia flexuosa & G. flexu.* & 0.00 & 1.34 & 0.02 & 0.14 \\
\hline Turborotalita quinqueloba & G. quing. & 0.00 & 1.14 & 0.12 & 0.22 \\
\hline Sphaeroidinella dehiscens & S. dehis.* & 0.00 & 0.85 & 0.07 & 0.17 \\
\hline Globorotalia truncatulinoides (L) & G. trunc. (L)* & 0.00 & 0.36 & 0.01 & 0.06 \\
\hline Globorotalia anfracta & G. anfra. & 0.00 & 0.34 & 0.00 & 0.04 \\
\hline Globorotalia hirsuta & G. hirsu. & 0.00 & 0.30 & 0.01 & 0.04 \\
\hline
\end{tabular}

Notes: Species labeled with an asterisk $(*)$ after their code abbreviation are those species used in the dissolution-resistant species $(\%)$ calculation. Dissolution-resistant species as defined by Cullen and Prell (1984). $\mathrm{L}=$ left coiling, and $\mathrm{R}=$ right coiling. $\mathrm{SD}=$ standard deviation.

The timing of these abundance spikes suggests a complex response to glacial/interglacial cycles.

Globigerina bulloides is a solution susceptible species that is commonly found in subpolar and upwelling environments (Bé, 1977) (Fig. 4). At Site 847, its abundance displays three different patterns of co-occurrence. G. bulloides is associated with $G$. ruber and $G$. sacculifer at the beginning of isotope stage 5 , throughout stages 11 to 14 , and during stage 20. In addition, $G$. bulloides occurs with the $G$. inflata spikes in TS1 and in TS 3 with Neogloboquadrina pachyderma (left-coiling).

A most interesting feature of the faunal variability at Site 847 was the presence of $N$. pachyderma (left-coiling) in large percentages between 0.70 and $0.80 \mathrm{Ma}$ (Fig. 4). The greatest relative abundance of this species was nearly $30 \%$ in Sample $138-847 \mathrm{C}-3 \mathrm{H}-1,90 \mathrm{~cm}$. The occurrence of this species is apparently restricted to Site 847 , rather than regional, because the species was not observed in similarly aged sediments from DSDP 572 (M.T. Chen, 1994) or Site 846 (Le et al., this volume). The faunal record from RC13-110 is not long enough to cover this time period. $N$. pachyderma (left-coiling) is most abundant in polar waters, with only a limited number of co-occurring species. However, at Site 847, N. pachyderma (left-coiling) is found co-occurring with a variety of other foraminifer species. This diversity could result from short cold events, high seasonality, or the displacement of SST as the dominant environmental variable controlling foraminifer abundances.

\section{Dissolution}

The sediments of the equatorial Pacific have a general pattern of high carbonate during glacial stages and low carbonate during interglacial stages (Farrell and Prell, 1989). The $\mathrm{CaCO}_{3}(\%)$ at Site 847 follows this general pattern. Dissolution in TS1 is characterized by large amplitude, short-term, variation (Fig. 5). Although this rapid variation can be seen in all three records, the amplitude of variation is clearly largest in the whole planktonic foraminifers (\%). Dissolution maxima occur in TS1 at $0.025,0.06,0.09$, and $0.11 \mathrm{Ma}$, although the timing of the event at 0.025 Ma varies slightly among the records. TS2 has two episodes of high dissolution, centered on 0.41 and $0.50 \mathrm{Ma}$, as defined by whole planktonic foraminifers (\%) and foraminifer flux. Coarse fraction (\%) is also low at $0.50 \mathrm{Ma}$, but is high at 0.41 $\mathrm{Ma}$. However, the changes in the other two indexes are large enough that these appear to be times of greater dissolution. In TS3, a minor dissolution event, located near $0.725 \mathrm{Ma}$, can be seen in all three records. A large dissolution maxima is centered on $0.775 \mathrm{Ma}$, although it is most notable in the whole planktonic foraminifers (\%).

Having documented times of high dissolution, we now need to determine their potential effects on the faunal record. Comparison of individual species records with the whole planktonic foraminifers (\%) record shows a mixed pattern of correlation. During the times of higher dissolution in TS1, the percent abundances of either one of the two dissolution-resistant species, $N$. dutertrei and $G$. menardii, increase, whereas the percent abundances of the more dissolutionsusceptible species, G. sacculifer, $G$. ruber, and $G$. bulloides, decrease. In TS2, the large dissolution event at $0.50 \mathrm{Ma}$ is reflected in the fauna, as was seen in TS1. However, during the dissolution event at $0.41 \mathrm{Ma}$, the faunal records show high relative abundances for the three dissolution-susceptible species as well as for the dissolutionresistant species, G. menardii. Again, in TS3, relative abundances of the dissolution susceptible-species are higher during dissolution maxima. Thus, the effect of dissolution on the fauna assemblages appears to vary over the length of our record.

Comparison of the dissolution-resistant species (\%) record with the whole planktonic foraminifer $(\%)$ record provides a more compact measure of the changing relationship between species abundance patterns and dissolution (Fig. 5). Instead of comparing numerous records of individual species with one or more dissolution indexes, this approach compares only two records. The two chosen indexes react inversely to dissolution; dissolution maxima should be characterized by low values for whole planktonic foraminifers (\%) but high values for dissolution-resistant species (\%). Visual inspection of these two records reveals a pattern similar to that found with the individual faunal records. In TS1 and the earlier portion of TS2 (0.48- 0.572 


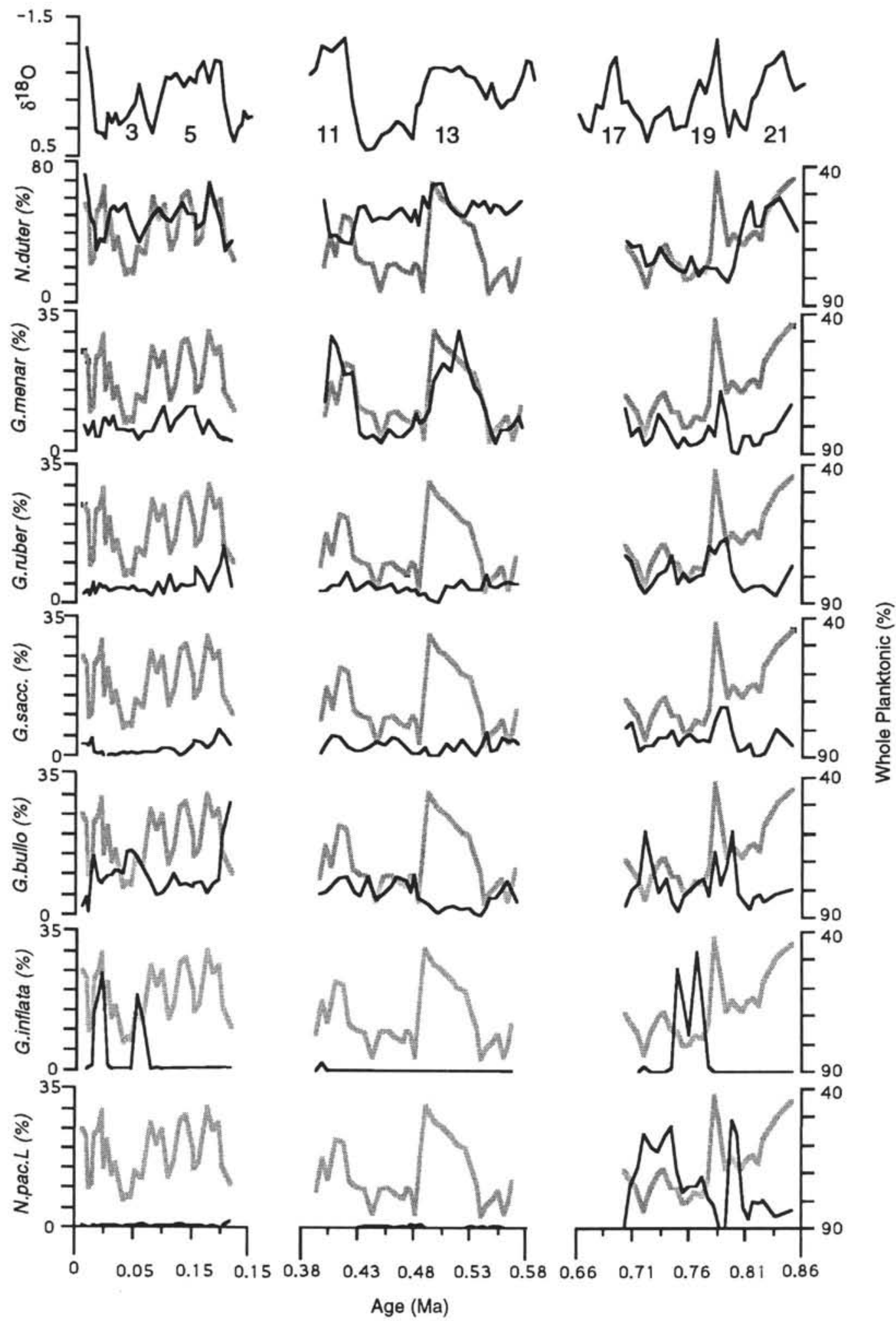

Figure 4. The relative abundance records of selected species are shown with the oxygen isotope record for Site 847 . The isotope stages are numbered for easy reference. The shaded, gray line reproduced with each species is the record of whole planktonic foraminifers (\%). It is included to facilitate the examination of the relationship between dissolution and species abundances. Poorer preservation appears toward the top of each graph. 


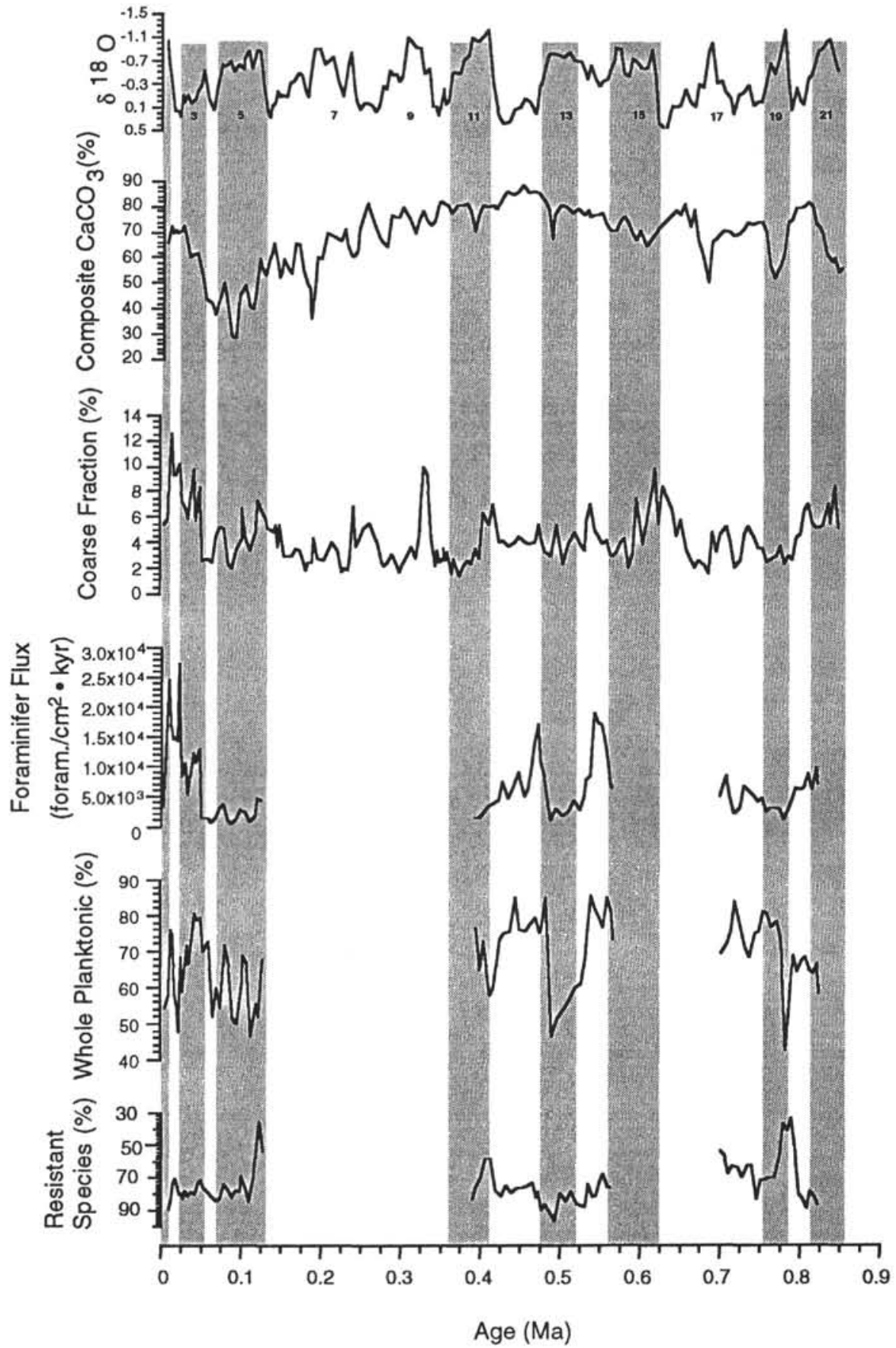

Figure 5. Preservation indexes used to assess the alteration of the foraminifer assemblages caused by dissolution at Site 847. For all indexes, better preservation is toward the top of the figure. The shaded boxes define selected interglacial stages for ease in comparing the series of graphs.

$\mathrm{Ma}$ ), the records show similar patterns of variation in dissolution. These intervals correspond to segments of the species abundance records in which enhanced dissolution resulted in low relative abundances for the dissolution-susceptible species and higher abundances for dissolution-resistant species. In TS3 and the later half of TS2 $(0.40-0.48 \mathrm{Ma})$, the two records show dissimilar patterns of dissolution variation. These intervals correspond to the sections of the species abundance records that show reduced dissolution effects as inferred from higher abundances of dissolution-susceptible species.

Scattergrams of the two dissolution indexes display this more clearly (Fig. 6). A linear regression line calculated by a least-squares method has been plotted on each graph solely as a reference to aid comparison. The character of the relationship between these two records changes with age. Moving from older samples to younger, the data cluster closer to the regression line and the line's slope changes from slightly positive to slightly negative. In relation to the sedimentary record at Site 847, the balance between ecological factors, which affect the living assemblage, and dissolution, which alters the sediment assemblage, has shifted.

\section{Sea-surface Temperature}

In the absence of dissolution effects, the abundance records of individual species from a core are an expression of the underlying eco- 
logic variation at that location. Use of statistical techniques provides a means for simplifying this multivariate species data as a first step toward inferring causation. Using the MAT to calculate SST results in the ultimate reduction to one variable, based on the assumption that temperature is a principle control on foraminifer species abundance. The SSTs calculated for Site 847 are presented in Figure 7. Five of the 89 samples were so dissimilar from the core tops in the database that no analogs could be found with dissimilarity values below 0.4 , the designated cutoff. These five samples occurred where the SST showed a rapid change, during glacial stages or preglacial transitions.

Three features of the SST record are important to note. The highest values for both warm and cold SST commonly occur on deglacials. First, in stages 5, 11, and 13, these highest values may also be matched by other SST values within the interglacial stage itself. Isotope stage 3 is a particular exception with the highest SSTs occurring late in the stage. Second, the response of SST in glacial stages has not been uniform. Stages $2,18,20$, and the stage $3 / 4$ boundary show sharp, largeamplitude changes in cold SST. Warm SST shows similar amplitude changes in stages 18 and 20 . In contrast, stages 12 and 14 show only small amplitude SST change. Third, the cold SSTs associated with the large-amplitude changes have values on the order of $12^{\circ}$ and $15^{\circ} \mathrm{C}$. These temperatures are much colder than the modern SST at Site 847.

The association of the statistically generated SST record with a particular environmental parameter must ultimately rest on an assessment of the physical relations involved. The timing of the SST changes in relation to the stages in a glacial/interglacial cycle and the inconsistency of response can provide information about these causal mechanisms. The very low values computed for cold SST confront us with two different options that can be valid either singly or in combination. Either the surface water has been much colder at times in the past, and our calculated SSTs are an accurate reflection of this; or the fauna are primarily responding to other oceanographic conditions, resulting in misleading SST estimates. As discussed below, we suggest that a combination of these two options is responsible for the foraminifer variation at Site 847.

\section{Q-mode Factor Composition}

A Q-mode factor analysis provides a way to simplify the faunal data into a specified number of variables. A four-factor model of the Site 847 foraminifer data (Table 3 and Fig. 8) will reconstruct $96.9 \%$ of the compositional structure of the samples. A fifth factor adds less than $2 \%$ more information.

With the exception of Factor 3, the factors are dominated by one species with very high factor scores. The other species in each factor have scores less than half those for the primary species. Therefore, the downcore patterns of the factors are much like the abundance patterns for the individual species. However, two advantages result from performing a Q-mode analysis rather than examining only the abundance records of individual species. This analysis produces a quantitative assessment of the amount of information contributed to the sums of squares by each of the individual factors. When using individual abundance records, the contribution of a particular species to the information in the total data set remains qualitative. In addition, the factors can be used to make comparisons with a database of modern core tops to facilitate oceanographic interpretation of downcore variation.

We have shown that the influence of dissolution on the faunal composition of assemblages has varied over the length of the record, but the factor loadings for our model are not primarily the effects of such dissolution. Each of the species with the highest factor scores in Factors 1,2, and 4 are dissolution-resistant species. Factor 3 is characterized by three highly correlated species, G. ruber, G. sacculifer, and $G$. menardii. The high correlation among these species must result from ecologic responses rather than from responses to dissolution, because $G$. ruber and $G$. sacculifer are dissolution-susceptible species, and $G$. menardii is a dissolution-resistant species. Therefore,
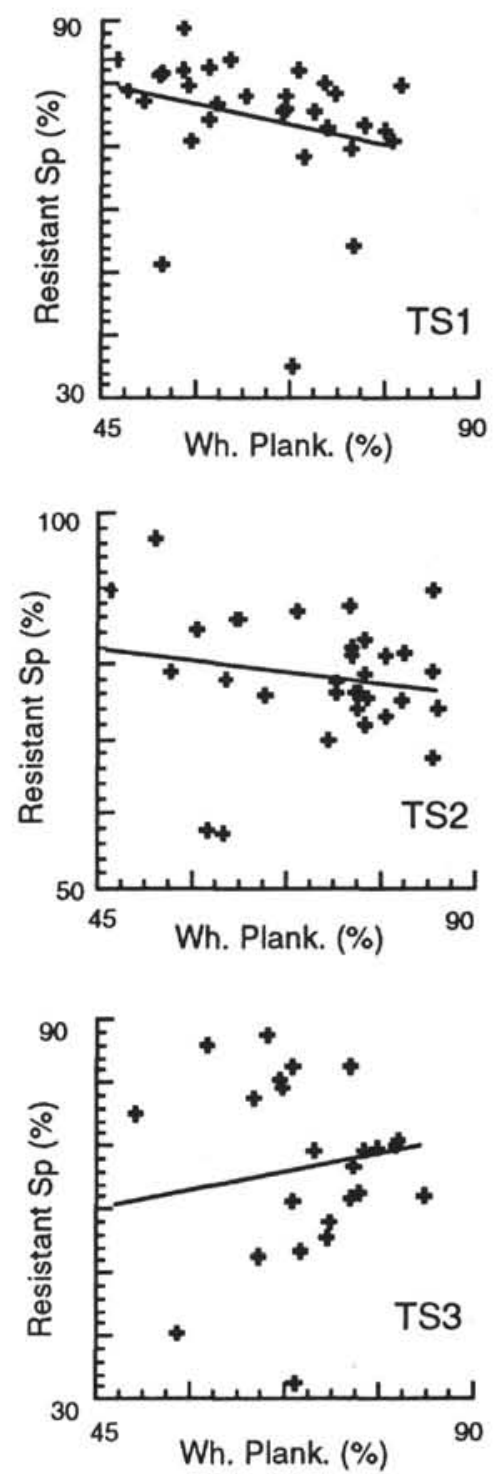

Figure 6. Correlation of the whole planktonic foraminifer (\%) record with the dissolution-resistant species (\%) record by time slice demonstrates the changing influence of dissolution on the faunal assemblages. The regression line is not included to suggest any quantitative relationship, but as an aid for demonstrating the changing nature of the relationship between the two records.

the response of Factor 3 to changes in the conditions that control carbonate dissolution is buffered.

Because variation in all four factors should be more strongly influenced by changes in ecological conditions, the relative independence of the four factors from dissolution can be seen in the correlation of each factor with whole planktonic foraminifers (\%) (Fig. 9). Each factor has a small characteristic range of factor-loading values. These small ranges have a moderate correlation with whole planktonic foraminifers (\%). In all four cases, the correlation coefficients would be reasonably good, but the response of the factor to change in dissolution is small. When correlating all loading values for each factor with whole planktonic foraminifers (\%), the correlations are very low; $r=0.29$, for Factor 3, is the highest correlation.

Factor 1 dominates the faunal record by explaining more than $57 \%$ of the sums of squares (Fig. 8). The factor principally represents the abundance of $N$. dutertrei, with minor contributions from $N$. pachyderma (right-coiling) and P-D Intergrade. The values of the loadings 
Table 3. Factor scores from the Q-mode analysis of Site 847 foraminifers.

\begin{tabular}{|c|c|c|c|c|}
\hline Species & Factor I & Factor 2 & Factor 3 & Factor 4 \\
\hline O. univ. & -0.0327 & 0.0105 & 0.0814 & -0.0818 \\
\hline G. cglob. & -0.0051 & -0.0004 & 0.0176 & -0.0028 \\
\hline G. ruber & -0.1484 & 0.0997 & 0.4215 & -0.1808 \\
\hline G. tenel. & -0.0078 & -0.0010 & 0.0317 & -0.0027 \\
\hline G. sacc. & -0.1058 & 0.0273 & 0.3048 & -0.1235 \\
\hline S. dehis. & -0.0023 & -0.0008 & 0.0091 & -0.0020 \\
\hline G. aequi. & -0.0060 & 0.0085 & 0.0405 & -0.0105 \\
\hline G. calid. & -0.0091 & 0.0013 & 0.0505 & -0.0082 \\
\hline G. bullo. & -0.1112 & 0.2143 & 0.2203 & -0.3033 \\
\hline G. falco. & -0.0133 & 0.0124 & 0.0419 & -0.0144 \\
\hline G. digit. & -0.0007 & -0.0030 & 0.0142 & -0.0142 \\
\hline G. rubes. & -0.0034 & -0.0014 & 0.0295 & -0.0001 \\
\hline G. quinq. & -0.0019 & 0.0096 & -0.0021 & -0.0042 \\
\hline N. pac. L & -0.2356 & 0.0566 & -0.1740 & -0.8229 \\
\hline N. pac. $\mathrm{R}$ & 0.0652 & 0.2977 & -0.2345 & -0.1000 \\
\hline N. duter. & 0.9039 & 0.1842 & 0.1582 & -0.2664 \\
\hline G. cglom. & -0.0017 & -0.0024 & 0.0178 & -0.0058 \\
\hline G. hexag. & -0.0132 & 0.0036 & 0.0873 & -0.0054 \\
\hline P. obliq. & -0.0307 & 0.0007 & 0.1082 & -0.0171 \\
\hline G. infla. & -0.1904 & 0.8749 & 0.0055 & 0.2367 \\
\hline G. trunc. L & -0.0021 & 0.0018 & 0.0040 & -0.0003 \\
\hline G. trunc, R & -0.0179 & -0.0099 & 0.0234 & -0.0583 \\
\hline G. crasf. & -0.0100 & 0.0390 & -0.0071 & -0.0251 \\
\hline P-D int. & 0.1807 & 0.2189 & -0.2161 & 0.0554 \\
\hline G. hirsu. & -0.0005 & -0.0004 & -0.0003 & -0.0020 \\
\hline G. scitu. & -0.0116 & 0.0036 & 0.0302 & -0.0163 \\
\hline G. anfra. & -0.0003 & 0.0000 & 0.0009 & -0.0001 \\
\hline G. menar. & 0.0296 & -0.0257 & 0.6393 & 0.1517 \\
\hline G. tumid. & -0.0009 & -0.0036 & 0.0437 & -0.0086 \\
\hline G. flexu. & 0.0005 & -0.0005 & 0.0004 & -0.0001 \\
\hline G. gluti. & -0.0670 & 0.0376 & 0.2775 & -0.0616 \\
\hline G. theyr. & -0.0165 & -0.0060 & -0.0018 & -0.0631 \\
\hline Sums of squares & 57.26 & 12.70 & 11.46 & 15.18 \\
\hline Cumulative sums of squares & 57.26 & 69.96 & 81.42 & 96.60 \\
\hline
\end{tabular}

Notes: Species mentioned in the text in relation to a particular factor are boxed. The principle species in each factor have scores printed in bold type. The variance and cumulative variance listed at the bottom of each column refer to the factor loading of the samples.

for this factor remain high through most of the record. Only in TS3 do the loadings decrease and remain at low levels, instead of quickly returning to the high levels present in the other time slices. The high loadings at the top of the core confirm that this factor is associated with modern upwelling. Particularly in TS1 and TS2, Factor 1 represents the dominant assemblage at Site 847.

Both Factors 2 and 4 are principally composed of species that are subpolar or polar in their modern distributions, $G$. inflata and $N$. pachyderma (left-coiling), respectively. Note that the negative values for Factor 4 represent an artifact of the factor analysis. The absolute values of the loadings are the important information for comparison among factors. Although high loadings for these two factors occur during glacial stages, the amplitudes of their variation are only of equal magnitude in TS3. The highest loadings for both factors do not consistently occur during the intervals studied here, but only in TS1 and TS 3 . If both Factors 2 and 4 have high loadings in the same glacial stage, they occur sequentially instead of concurrently. Factor 3 is composed of species that are characteristic of tropical/subtropical waters: $G$. menardii, $G$. ruber, and $G$. sacculifer. High loading values for this factor occur on deglacial transitions. Of the four factors, the variation of Factor 3 is most consistent in all three time slices.

The variability of the factors in TS 3 has two unique characteristics when compared with the other two time slices. In TS3, three of four records have larger amplitude variability than is present in time slices 1 and 2 . Also, this is the only time slice in which the variation involves a succession that includes all four factors.

\section{Geographic Distribution of Factors}

Q-mode factor analysis is commonly used on core-top abundance data to examine the spatial distribution of assemblages. These factors are then applied to the downcore faunal variations of a core and used
Sea Surface Temperature $\left({ }^{\circ} \mathrm{C}\right)$
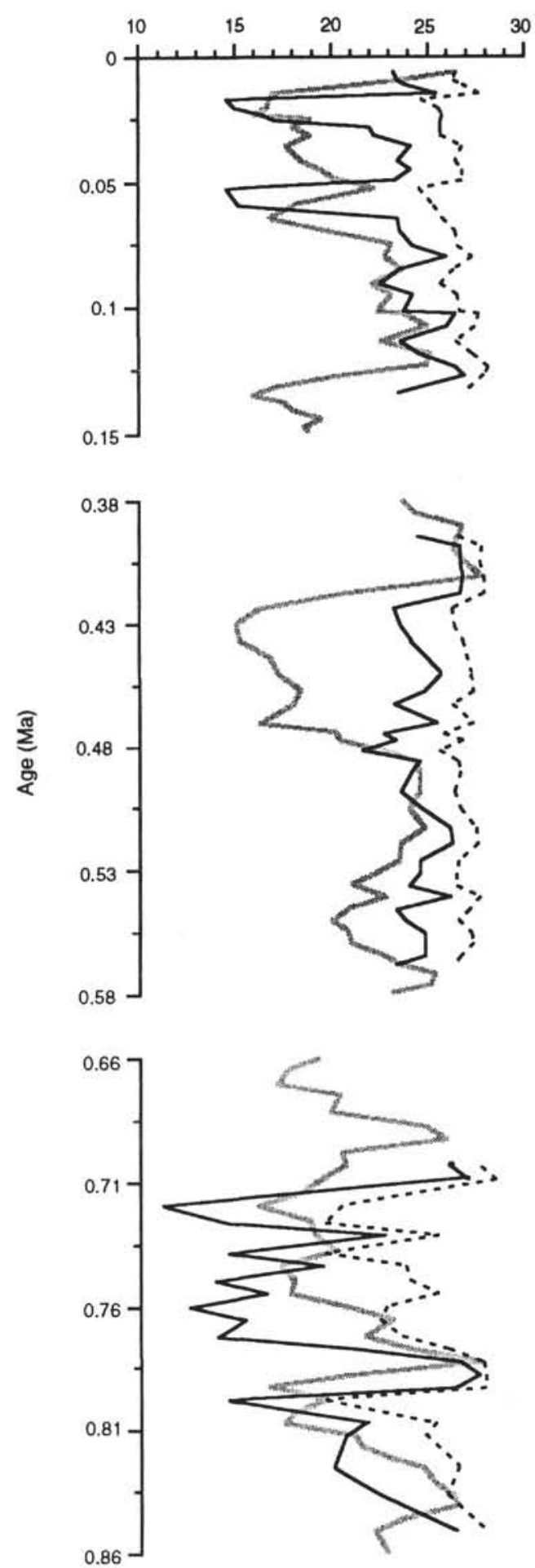

Figure 7. Site 847 sea-surface temperatures were calculated using MAT. Both cold and warm season temperatures are shown here. The cold SSTs are associated with modern upwelling. The shaded gray line is the $\delta^{18} \mathrm{O}$ record for the core. It is included so the temperature records can be easily compared to the isotope stages. 


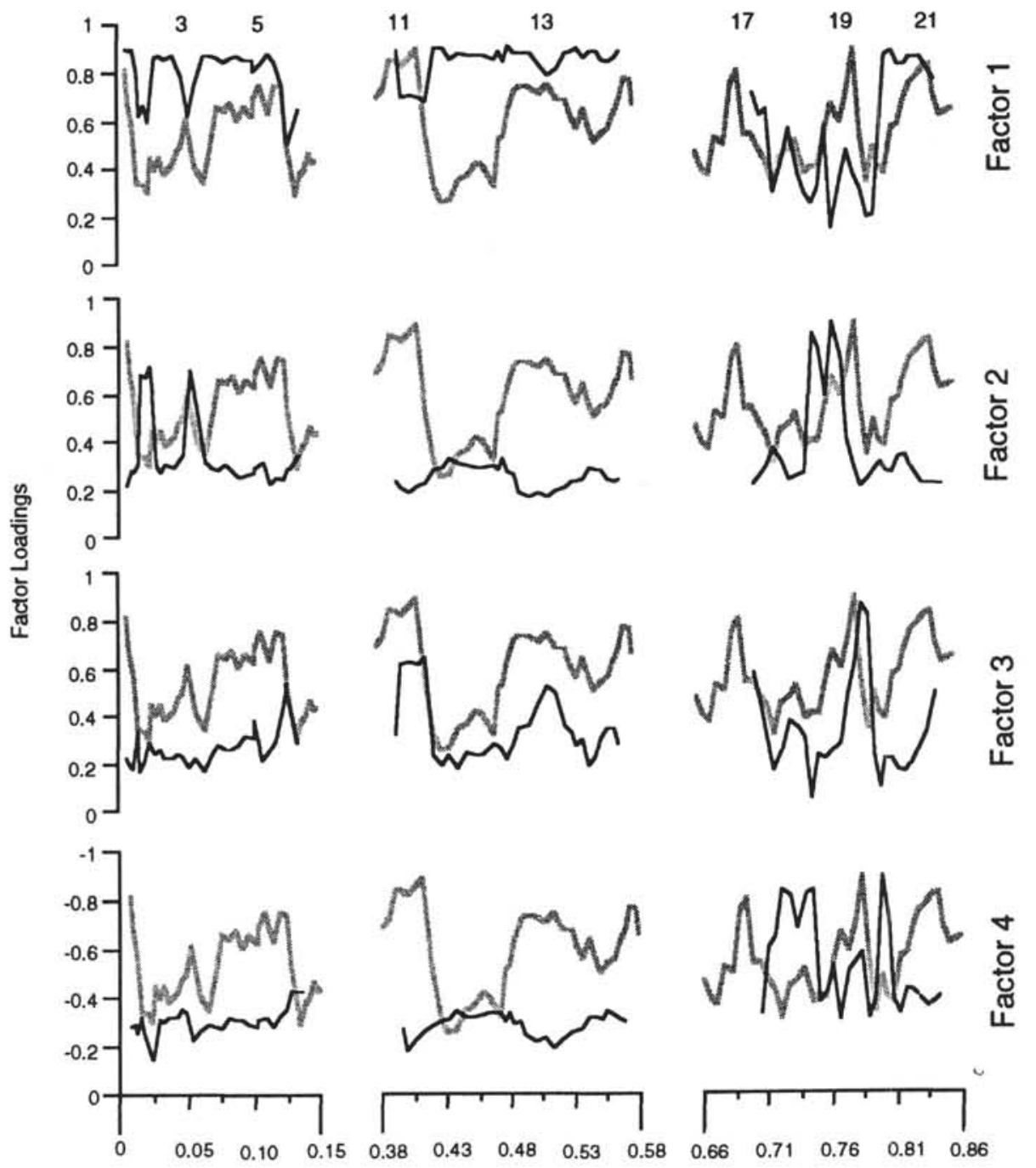

Age (Ma)

Figure 8. Downcore records of the four factors from the Q-mode analysis. Negative values for Factor 4 are an artifact of the calculation technique. The factor is graphed so that all four plots display increasingly important weightings toward the top of the figure. The shaded gray line is the $\delta^{18} \mathrm{O}$ record for the core. It is included so the factors can be easily compared to the isotope stages.

to infer the changing influence of water masses at the site. With this approach, downcore variations are cast in terms of modern patterns. This method was used by the CLIMAP Project members (CLIMAP, 1976; CLIMAP, 1981) for the world ocean and by Romine (1982) and Schramm (1985) for the equatorial Pacific. Here, we take an alternative approach in projecting core-top faunal data in terms of the factors derived from the Q-mode analysis of the downcore data. This application allows us to identify areas in the modern ocean that are faunally and, by inference, oceanographically analogous to the conditions that produced the downcore assemblages. This approach is advantageous because it eliminates the need to make a priori assumptions about the geographic affinities of downcore faunas. The communality of each core-top sample with the factors serves as a measure of the proportion of information in the modern core-top assemblage that the downcore factors explain. In other words, the communality explains how well the combination of four factors for Site 847 describe any given modern core-top assemblage. The similarity between the species composition of a particular factor and the composition of the modern assemblage will be indicated by the value of the factor loading.
The factors for Site 847 were projected onto the modified Prell (1985) core-top database. Instead of restricting the analysis to the Pacific Ocean, the world database was used to maximize the range of available oceanographic conditions. This method of analysis provided two additional benefits for this study. Dissolution has significantly altered the faunal compositions of many of the core tops in the Pacific Ocean, whereas the faunal record at Site 847 shows a range of preservation states. First, using a database from all oceans provides more well-preserved core-top samples for comparison. Second, using the world database decreased the impact of taxonomic differences among investigators. The faunal records in the database have been developed using different criteria for distinctions among $N$. dutertrei, P-D intergrade, and $N$. pachyderma (right-coiling). As an example, the vast majority of the core tops in the Pacific subset of the database do not use the P-D intergrade classification.

The relative contribution of each factor in explaining the core-top assemblage was determined by inspection, with the joint criteria of the factor loading equaling or exceeding 0.8 and the communality for the sample being at least 0.8 . The robustness of the locations for the 

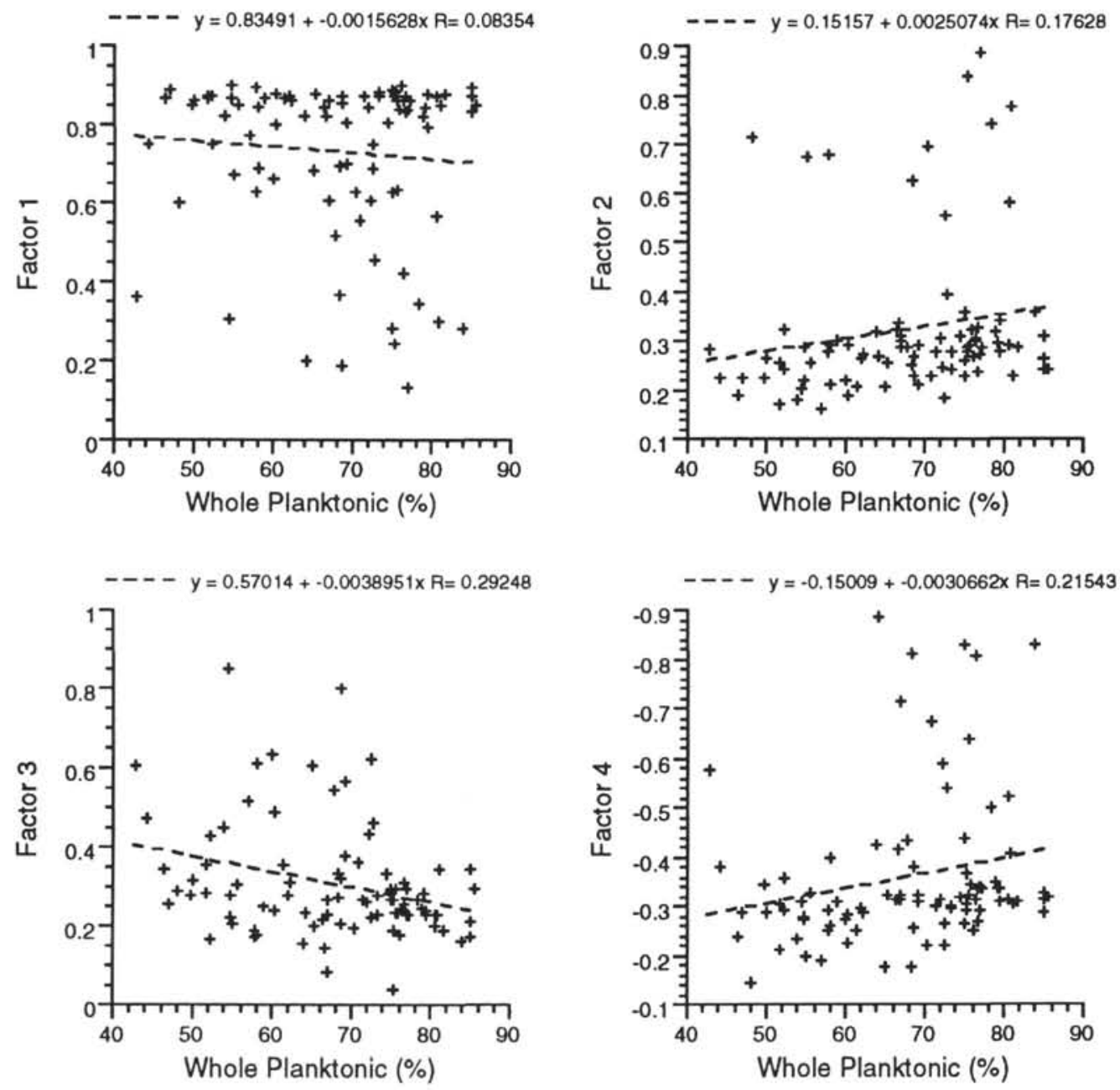

Figure 9. Correlation of each factor with whole planktonic foraminifers (\%) demonstrates that variation in the factors is not strongly dependent on variation in dissolution. The regression line is a least-squares fit. The plots are arranged so that the highest weightings for the factor are toward the top.

factors was checked by comparison with results from a dissimilarity analysis. The modified Prell (1985) database was searched for faunal analogs for those Site 847 samples that had the highest factor loadings. The squared chord distance measure (Overpeck et al., 1985) was used to find multivariate dissimilarities between sample pairs. The ten best analogs for each sample were selected and their geographic locations examined. The distribution of these best analogs matched the distribution of factors.

Figure $10 \mathrm{~A}$ presents the geographic distributions of all core-top samples in the database for which the communalities equaled or exceeded 0.4 with the four-factor model. Figure 10B displays the geographic distribution of the four factors for Site 847. The core-top samples most similar to Factor 1 (dominated by $N$. dutertrei) are located in the eastern equatorial Pacific Ocean. Although the factor extends as far north as $10^{\circ} \mathrm{N}$, the distribution of the factor matches the location of the cold-water tongue resulting from upwelling of the EUC. This distribution confirms the association of Factor 1 with the equatorial upwelling on the basis of its high loadings in samples from the top of the core. Five samples belonging to Factor 1 define a secondary area that extends between $20^{\circ}$ and $40^{\circ} \mathrm{S}$ and are perhaps an indication of the Temperate Surface Water (Wyrtki, 1966) with cooler temperatures and salinities close to those in the core of the upwelling from the EUC.

The core-top samples most similar to Factor 2 (dominated by $G$. inflata) have a geographic distribution that can be divided into North- ern and Southern Hemisphere areas with different oceanographic characters. The southern location of the factor is centered on the Subtropical Convergence in the south Atlantic and Indian oceans. The low communalities for this factor in the southern Pacific Ocean resulted from the lack of a P-D intergrade classification in the faunal analysis of these core tops. Although the values are slightly lower than those set for cut-off values, a regional pattern of higher communalities and factor loadings does occur in the southern Pacific. On the eastern edge of the southern Atlantic Ocean, the distribution extends equatorward with the flow of the eastern boundary current. If this pattern holds for the South Pacific, this factor could be related to the Peru Current. In addition, high loadings and communalities for this factor are located in the northwest Atlantic and Pacific oceans. The Northern and Southern Hemisphere sites have similar winter seasurface temperatures $\left(18^{\circ}-16^{\circ} \mathrm{C}\right)$. However, seasonality at the two sites is different, $10^{\circ}$ to $12^{\circ} \mathrm{C}$ in the Northern Hemisphere distribution vs. $4^{\circ} \mathrm{C}$ in the Southern Hemisphere distribution (Robinson, 1976; Gordon et al., 1982). At the sites of the southern core tops, the water column is homogeneous, whereas the northern sites have a seasonal development of a shallow thermocline. However, Bé (1977), in Figure 6 , shows that the months for peak $G$. inflata abundances at Stations Delta and Echo in the North Atlantic are the months of November through April, a period when the water column has a deep thermocline. In addition, both the northern and southern sites have high oxygen concentrations. 

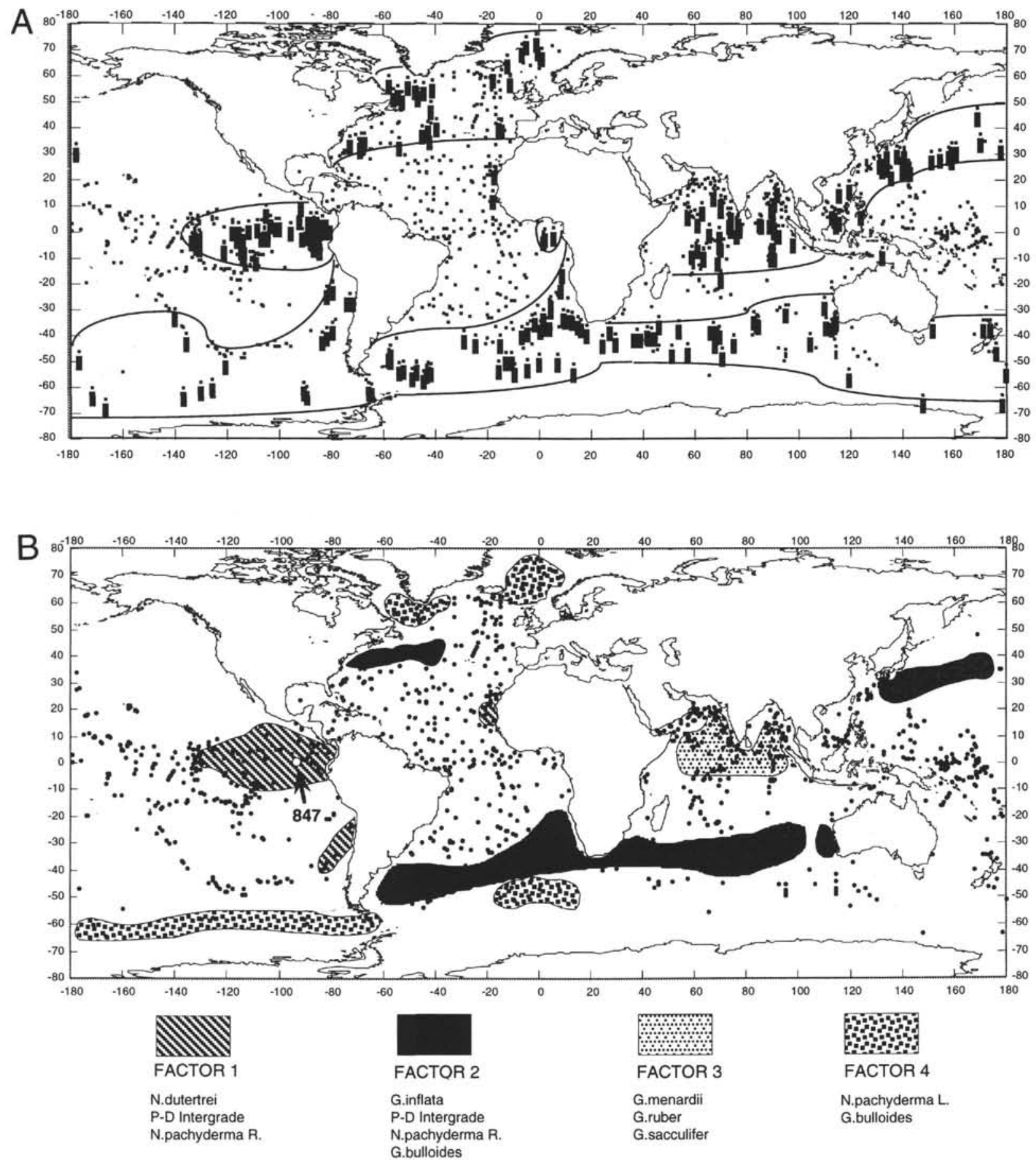

Figure 10. A. The communalities between the modern species assemblages and the combination of the four factors for Site 847 that are equal to or above 0.4 are plotted. The location of any core top with a communality below 0.8 is shown as a small dot, and any core top with a communality equal to or greater than 0.8 is shown with a large rectangle. The 0.8 contour is shown. $\mathbf{B}$. The geographic distribution of modern species assemblages that are similar to the species compositions of the four Site 847 factors when applied to the modified Prell (1985) database. Shaded areas denote regions where the communality was equal to or exceeded 0.8 and the loading on the particular factor was equal to or exceeded 0.8 .

Core tops having a fauna similar to Factor 3 (dominated by tropi$\mathrm{cal} /$ subtropical species) have a geographic distribution that is concentrated in the Indian Ocean north of $10^{\circ} \mathrm{S}$. Core tops from the tropical regions of both the Atlantic and Pacific oceans had weightings in the $0.5-0.7$ range and communalities in the range $0.4-0.6$. Although the tropical areas of the Atlantic, Indian, and central Pacific oceans have comparably warm sea-surface temperatures, the region of the Indian Ocean north of $10^{\circ} \mathrm{S}$ is characterized by a shallow mixed layer that varies seasonally to a maximum of $120 \mathrm{~m}$, by high levels of nutrients, and by low oxygen levels close to the surface (Wyrtki, 1971). The Atlantic Ocean has a deeper mixed layer with little variation. The tropical region of the central and western Pacific Ocean has a deep mixed layer that seasonally varies from 200 to $400 \mathrm{~m}$ (Robinson, 1976).

Modern samples most similar to Factor 4 (dominated by $N$. pachyderma (left-coiling) have a polar distribution that is controlled by the core-top pattern of abundance for $N$. pachyderma (left-coiling) and 
G. bulloides. Sediment trap data from the North Pacific demonstrate that both foraminifer species are most abundant in the spring. During this time, the water is cold, isothermal, and nutrient rich (Reynolds and Thunell, 1985; Sautter and Thunell, 1989). Samples with high loadings for Factor 4 might come from times when the water column was coldest, although not necessarily as cold as $10^{\circ} \mathrm{C}$. Of equal importance might be the presence of a very deep mixed layer and high nutrient availability.

\section{DISCUSSION}

We have attempted to constrain some of the oceanographic processes occurring at Site 847 throughout the Pleistocene by evaluating three variables: (1) the species composition of the faunal factors at this site; (2) the geographic distribution of these factors; and (3) the link between faunal change and ice volume fluctuations. The apparent association of each factor with a particular part of a glacial cycle led us to evaluate these three variables within the conceptual framework of the idealized glacial/interglacial cycle proposed by Imbrie et al. (1992). This process model is divided into four stages, preglacial, glacial, deglacial, and interglacial, and was designed to explain a generic late Pleistocene glacial cycle. This model is useful for our interpretation of the Site 847 factors because the four stages are characterized by changes in specific elements of the climate system. For our purposes, the two most important parameters in the model are the extent of Antarctic sea ice, which determines the location of the maximum westerly winds with associated mode water formation, and the latitudinal temperature gradient, which determines the strength of the wind system (Imbrie et al., 1992).

Upwelling similar to the modern has been the dominant oceanographic process at Site 847 during both glacial and interglacial stages. This finding is based on the high loadings of Factor 1 over more than half of the past $0.60 \mathrm{~m} . \mathrm{y}$. Equatorial upwelling of the EUC is characteristic of Site 847 in the modern interglacial period and can serve as a model for all interglacial stage upwelling over this $0.60 \mathrm{~m} . \mathrm{y}$. period. We propose that during a glacial stage, the components of the upwelling system may have been affected by a shift in climate, but any changes would offset each other so that oceanographic conditions at Site 847 should be little different than those of an interglacial period. Specifically, during a glacial stage, the increased pole to equator temperature gradient would result in stronger trade winds, which would presumably increase the zonal equatorial sea-surface slope above modern levels. Because this slope, essentially a pressure gradient, controls the flow of the EUC, one would expect greater flow during glacials. Supporting the greater flow of the EUC, mode water formation also might increase moderately with the increased wind strength. Concomitant with increased mode water formation, the site of its formation would shift equatorward because of the northward shift of the maximum westerlies. The new location of mode water formation would have new characteristics for the surface water. Were the shift in the location of mode water formation on the order of $4^{\circ}$ equatorward, consistent with the estimate of Howard and Prell (1992), this shift would offset any general decrease in the sea-surface temperature of the magnitude estimated by CLIMAP (1981). Therefore, the mode water entering the EUC during the glacial stage of a cycle should have approximately the same temperature as the mode water that entered during an interglacial stage. Also, during the glacial stage of a cycle, the amount of water from the EUC involved in upwelling might possibly increase with the more vigorous circulation. A reasonable assumption might be that the ratio between the upper layer core water and the lower layer mode water would decrease as upwelling extent deepened. This situation would tend to decrease slightly the surface temperature at Site 847. However, the foraminifer data provide little evidence for a change in sea-surface temperature when comparing glacial and interglacial stages. Were the foraminifers primarily most sensitive to water column structure and secondarily to sea-surface temperature, only large changes in temperature would be recorded in the sedimentary record.

Imbrie et al. (1992) proposed in their model that during a deglacial state Subantarctic Mode Water formation would slow down as the westerlies decreased in strength and moved south in concert with the retreat of the sea ice. This would reduce the amount of mode water entering the EUC to form the lower layer mode water. In response, either the upwelling at the equatorial divergence would be reduced or the amount of water entering the EUC as upper layer core water would increase because the upwelling can be thought of as closing the system that ventilates the thermocline (Toggweiler et al., 1991). The upper layer core water is warmer and saltier, and it has reduced oxygen and nutrient levels when compared to the lower layer mode water. Decreased upwelling would result in a deepening of the thermocline or in a warming of the isotherms comprising the thermocline because of the change in source-water properties. If the thermocline deepened, a seasonal thermocline might develop over this lowered permanent thermocline in response to the seasonal reduction in wind intensity. In addition, the gradient across the nutricline would strengthen and the subsurface oxygen levels would be reduced. These sets of conditions are similar to the current oceanographic conditions in the geographic distribution of Factor 3. The pattern of variation in Factors 1 and 3 for the intervals examined during the past 0.60 m.y. demonstrates the unchanging nature of the structure of the water column at Site 847 as upwelling continues during glacial and interglacial stages. Only during deglacial stages, times of weakest wind strength, does upwelling decrease and the structure of the water column change. Our emphasis on a changing thermocline structure is consistent with previous work using foraminifers in the eastern equatorial and subtropical Pacific. Luz (1973) used dissolution-resistant foraminifers in 24 core tops to develop mappable factors. These factors correlated better with thermocline depth and temperature at the $200 \mathrm{~m}$ level than with winter sea-surface temperature.

This proposed pattern of responses to glacial/interglacial variability is only marginally compatible with a $5^{\circ}$ southerly shift in the tradewind belt proposed by Romine (1982) in a study of radiolarian assemblages and supported by Rea et al. (1986) with an analysis of eolian grain size records. For upwelling to continue at Site 847, the surface ocean currents can shift south no more than $4^{\circ}$ because the equatorial divergence is dependent on a westerly current flow. Any greater shift would place the site in an easterly surface current flow and result in convergence rather than divergence. Even the alignment of the boundary between the NECC and the SEC with Site 847 would reduce the magnitude of upwelling. Indeed, Schramm (1985) concluded that changes in the strength and location of the trade winds were insufficient to explain variation in longer radiolarian records.

In TS3, some of the factor variation is similar to that in the younger slices of the record. Upwelling (Factor 1) is the dominant oceanographic process during interglacials, and upwelling is reduced during deglacials (Factor 3). However, Factors 2 and 4 become important during glacials, replacing Factor 1. With the EUC and mode water formation as the proposed link between Site 847 and the Southern Ocean, additional avenues for variation exist, thus increasing the complexity of the system. Increased complexity can accommodate more numerous combinations of the climate boundary conditions that affect oceanographic processes.

At Site 847, Factor 2 has high loadings during some glacials but not all, specifically at stages 2 and 4 ; and across the Stage 18/19 transition. In addition, large, short-term $G$. inflata increases in abundance have been documented in cores from the southeast tropical Pacific (Luz, 1973), at nearby DSDP Site 572 (Chen, 1994) and ODP Site 846 (Le et al., this volume), and in piston core RC13-110 (A. Mix, pers. comm., 1993). Any proposed mechanism for increased $G$. inflata abundance must account for the regional appearance of these abundance spikes. Luz (1973) noted the possible connection between $G$. inflata abundance and subsurface oxygen levels. The establish- 
ment of an unusually strong latitudinal temperature gradient would greatly increase wind system strength. Associated with this may be increased creation of Subantarctic Mode Water as well as increased upwelling at the equatorial divergence. Intensification of these two processes would have increased the ventilation of the equatorial thermocline resulting in colder, more oxygenated water at Site 847. Such a mechanism is an effective way to increase regional oxygen levels because of the great dispersal of the EUC water upon reaching the eastern equatorial Pacific. Although the Peru Current might become better oxygenated during glacials, it is unlikely that the current could increase in strength enough to produce the observed regional pattern in the $G$. inflata records.

Factor 4 (dominated by $N$. pachyderma left-coiling) has high loadings during glacial stages 18 and 20 . Because the factor has high loadings only during the oldest part of the Site 847 record, this short time slice does not provide much information from which to theorize. Perhaps this time represents an even greater intensification of Subantarctic Mode Water formation. Had the Subtropical Convergence shifted north farther than the Antarctic Polar Front during these stages, the area for mode water formation might have increased. Increased area of formation and increased wind strength could have led to greatly increased mode water formation. Whatever the mechanism, water column characteristics at Site 847 must have changed enough for $N$. pachyderma $\mathrm{L}$ to flourish. If a reduction in SST were one of these changes, then other sites in the tropical region, DSDPSite 572 (Chen, 1994), and ODP Site 846 (Le et al., this volume) could have remained unaffected because solar radiation would have modified the water temperature flowing out of the tongue of cool water.

The $\delta^{18} \mathrm{O}$ gradient between $N$. dutertrei, a thermocline-dwelling species, and $G$. sacculifer, a shallow-dwelling species, can provide information about changes in the mixed layer (Farrell et al., this volume). A comparison of the Site 847 factors with the isotope gradient for the site can possibly serve as a test of some of the ideas we have discussed. However, the relationships involved appear to be very complex with no clear overall pattern emerging (Fig. 11). One smaller scale feature is interesting. The variation in the records of all four factors in TS3 seem to differ qualitatively from their variation in TS1 and TS2. This change in character appears to be first evident around $0.78 \mathrm{Ma}$, with the sharp drop in the factor loadings for Factor 1. Note how this drop matches the large drop in the isotope gradient. In TS2, the gradient exhibits a long-term increase to its largest values in TS1 and the very oldest section of TS3. Clearly, variation in these records is the result of complicated interactions between variation in mixed layer depth, the temperature defining the thermocline, and surface temperature.

\section{SUMMARY}

The faunal record from Site 847 provides a means to study the history of the equatorial divergence and the EUC. Faunal variability for the entire period was atypically large for a tropical site (Moore et al., 1981), with ten species having maximum abundances above the $10 \%$ level for at least part of the record. The modern faunal provinces represented by these assemblages range from the tropical to the polar.

Although dissolution has modified the sedimentary assemblages, the importance of this process has varied over the length of the record. In the older time slice of the record, the effects of ecological variables on the final sedimentary assemblages were of greater importance than the dissolution effects. The factors generated by a Q-mode analysis were uncorrelated with whole planktonic foraminifers $(\%)$, which allowed us to focus on variation in surface water characteristics.

The Site 847 factors, when applied to a modern core-top database, show a systematic geographic distribution. In combination with a time series of each factor, this analysis provided a means for constraining past oceanographic variability at Site 847 .

Faunal abundances at Site 847 appear to be influenced by mixed layer depth, change in the partitioning between two source areas of supply of the EUC, and sea-surface temperature. The pattern of variation in the factors derived from the foraminifer abundances implies strong upwelling during both glacial and interglacial stages of a complete climate cycle. Variability in mixed layer depth results from changes in the strength of the equatorial upwelling in response to equatorial winds. Glacial to interglacial transitions are the principle times of reduction in equatorial upwelling.

Subantarctic Mode Waters may provide a link between the Southern Ocean and the eastern tropical Pacific on geologic time scales. At Site 847 , faunal data are consistent with variability in mode water formation, implying changing oxygen and nutrient levels in the EUC, as well as changing sea-surface temperatures. In addition, the interaction between variability in the character of the EUC and in the strength of equatorial upwelling might have changed the gradient within the thermocline as well as shifted the isotherms that comprise it.

Future work needs to include calculation of SST with radiolarian abundance data as well as with any available chemical measures. Comparison of high-resolution records from Southern Ocean and eastern equatorial Pacific locations will better define the relationship between these two areas under varying stages of a glacial cycle. Synthesis of these results with a transect of cores in the eastern tropical Pacific will be necessary to determine of the geometry of the equatorial current system during all stages of a glacial cycle.

\section{ACKNOWLEDGMENTS}

The authors are most grateful to Carmen Cors for her laboratory assistance and to April Martin for her expert technical guidance, without which this study would not have been possible. W.L. Prell was a source of much needed advice and suggestions. We thank Alan Mix and Min-Te Chen for providing unpublished data, and Frances Parker and Jim Cullen for providing data on the distribution of $N$. pachyderma, left- and right-coiling. Jianning Le thoughtfully provided an advance copy of his study of Site 846 . The manuscript benefited by thoughtful reviews from W. Howard, L.C. Peterson, and an anonymous reviewer. This work was supported by grants from JOI/USSAC (TAMRF-20528) (J. Farrell) and NSF/ATM-8812589 (W.L. Prell).

\section{REFERENCES $*$}

Bé, A.W.H. (Ed.), 1967. Foraminifera families: Globigerinidae and Globorotalidae, fiche No. 108. In Fraser, J.H. (Eds.), Fisches d'Identification du Zooplankton. Conseil Internat. l'Exploration Mer, Charlottenlund, Sheet 108.

Bé, A.W.H., 1977. An ecological, zoogeographic and taxonomic review of Recent planktonic foraminifera. In Ramsay, A.T.S. (Ed.), Oceanic Micropaleontology (Vol. 1): London (Academic Press), 1-100.

Berger, W.H., 1970. Planktonic foraminifera: selective solution and the lysocline. Mar. Geol., 8:111-138.

1973. Biogenous deep-sea sediments: production, preservation, and interpretation. In Riley, J.P., Chester, R. (Ed.), Chemical Oceanography: London (Academic Press), 266-326.

Broecker, W.S., and Peng, T.-H., 1982. Tracers in the Sea: Palisades, NY (Eldigio Press).

Bryden, H.L., and Brady, E.C., 1985. Diagnostic model of the three-dimensional circulation in the upper Equatorial Pacific Ocean. J. Phys. Oceanogr., 15:1255-1273.

Chen, M.-T., 1994. Late Quaternary paleoceanography of the equatorial IndoPacific Ocean: a quantitative analysis based on marine micropaleontology data (Ph.D. thesis). Brown Univ.

CLIMAP Project Members, 1976. The surface of the ice-age Earth. Science, 191:1131-1137.

, 1981. Seasonal reconstructions of the Earth's surface at the last glacial maximum. Geol. Soc. Am., Map and Chart Ser., MC36.

\footnotetext{
-Abbreviations for names of organizations and publications in ODP reference lists follow the style given in Chemical Abstracts Service Source Index (published by American Chemical Society).
} 
Cullen, J.L., and Prell, W.L., 1984. Planktonic foraminifera of the northern Indian Ocean: distribution and preservation in surface sediments. Mar. Micropaleontol., 9:1-52.

Farrell, J.W., and Prell, W.L., 1989. Climatic change and $\mathrm{CaCO}_{3}$ preservation: an 800,000 year bathymetric reconstruction from the central equatorial Pacific Ocean. Paleoceanography, 4:447-466.

Gordon, A.L., Molinelli, E.J., and Baker, T.N., 1982. Southern Ocean Atlas: New York (Columbia Univ. Press).

Hagelberg, T., Shackleton, N., Pisias, N., and Shipboard Scientific Party, 1992. Development of composite depth sections for Sites 844 through 854 . In Mayer, L., Pisias, N., Janecek, T., et al., Proc. ODP, Init. Repts., 138 (Pt. 1): College Station, TX (Ocean Drilling Program), 79-85.

Howard, W.R., and Prell, W.L., 1992. Late Quaternary surface circulation of the southern Indian Ocean and its relationship to orbital variations. Paleoceanography, 7:79-117.

Imbrie, J., Boyle, E.A., Clemens, S.C., Duffy, A., Howard, W.R., Kukla, G., Kutzbach, J., Martinson, D.G., McIntyre, A., Mix, A.C., Molfino, B., Morley, J.J., Peterson, L.C., Pisias, N.G., Prell, W.L., Raymo, M.E., Shackleton, N.J., and Toggweiler, J.R., 1993. On the structure and origin of major glaciation cycles, 1. Linear responses to Milankovitch forcing. Paleoceanography, 7:701-738.

Imbrie, J., Hays, J.D., Martinson, D.G., McIntyre, A., Mix, A.C., Morley, J.J., Pisias, N.G., Prell, W.L., and Shackleton, N.J., 1984. The orbital theory of Pleistocene climate: support from a revised chronology of the marine $\delta^{18} \mathrm{O}$ record. In Berger, A., Imbrie, J., Hays, J., Kukla, G., and Saltzman, B. (Eds.), Milankovitch and Climate (Pt. 1): Dordrecht (D. Reidel), 269305.

Imbrie, J., and Kipp, N.G., 1971. A new micropaleontological method for quantitative paleoclimatology: application to a late Pleistocene Caribbean core. In Turekian, K.K. (Ed.), The Late Cenozoic Glacial Ages: New Haven, CT (Yale Univ. Press), 71-181.

Kipp, N.G., 1976. New transfer function for estimating past sea-surface conditions from sea-bed distribution of planktonic foraminiferal assemblages in the north Atlantic. In Cline, R.M., and Hays, J.D. (Eds.), Investigation of Late Quaternary Paleoceanography and Paleoclimatology. Mem.-Geol. Soc. Am., 145:3-41.

Klovan, J.E., and Imbrie, J., 1971. An algorithm and FORTRAN-IV program for large-scale Q-mode factor analysis. Math. Geol., 3:61-78.

Luz, B., 1973. Stratigraphic and paleoclimatic analysis of Late Pleistocene tropical southeast Pacific cores. Quat. Res., 3:56-72.

McCartney, M.S., 1982. The subtropical recirculation of mode waters. J. Mar. Res., 40:427-464.

Montgomery, R.B., and Stroup, E.D., 1962. Equatorial Waters and Currents at $150^{\circ} \mathrm{W}$ in July-August 1952: Baltimore (Johns Hopkins Press).

Moore, T.C., Jr., Hutson, W.H., Kipp, N., Hays, J.D., Prell, W.L., Thompson, and Boden, G., 1981. The biological record of the ice-age ocean. Palaeogeogr., Palaeoclimatol., Palaeoecol., 35:357-370.

Overpeck, J.T., Prentice, I.C., and Webb, T., 1985. Quantitative interpretation of fossil pollen spectra: dissimilarity coefficients and the method of modern analogs. Quat. Res., 23:87-108.

Pak, H., and Zaneveld, J.R.V., 1974. Equatorial front in the Eastern Pacific Ocean. J. Phys. Oceanogr., 4:570-578.

Parker, F.L., 1962. Planktonic foraminiferal species in Pacific sediments. Micropaleontology, 8:219-254.

Parker, F.L., and Berger, W.H., 1971. Faunal and solution patterns of planktonic Foraminifera in surface sediments of the South Pacific. Deep-Sea Res. Part A, 18:73-107.
Peterson, L.C., and Prell, W.L., 1985. Carbonate dissolution in Recent sediments of the eastern equatorial Indian Ocean: preservation patterns and carbonate loss above the lysocline. Mar. Geol., 64:259-290.

Prell, W.L., 1985. The stability of low-latitude sea-surface temperatures: an evaluation of the CLIMAP reconstruction with emphasis on the positive SST anomalies. Dept. Energy Tech. Rep., TR-025.

Prentice, M.C., 1980. Multidimensional scaling as a research tool in Quaternary palynology: a review of theory and methods. Rev. Palaeobot. Palynol., 31:71-104.

Rea, D.K., Chambers, L.W., Chuey, J.M., Janecek, T.R., Leinen, M., and Pisias, N.G., 1986. A 420,000-year record of cyclicity in oceanic and atmospheric processes from the eastern Equatorial Pacific. Paleoceanography, 1:577-586.

Reynolds, L., and Thunell, R.C., 1985. Seasonal succession of planktonic foraminifera in the subpolar North Pacific. J. Foraminiferal Res., 15:282-301.

Robinson, M.K., 1976. Atlas of North Pacific Ocean Monthly Mean Temperatures and Mean Salinities of the Surface Layer: Washington (Dept. of the Navy).

Romine, K., 1982. Late Quaternary history of atmospheric and oceanic circulation in the eastern equatorial Pacific. Mar. Micropaleontol., 7:163-187.

Sautter, L.R., and Thunell, R.C., 1989. Seasonal succession of planktonic foraminifera: results from a four-year time-series sediment trap experiment in the northeast Pacific. J. Foraminiferal Res., 19:253-267.

Schramm, C.T., 1985. Implications of radiolarian assemblages for the Late Quaternary paleoceanography of the eastern equatorial Pacific. Quat. Res., 24:204-218.

Shackleton, N.J., Berger, A., and Peltier, W.R., 1990. An alternative astronomical calibration of the lower Pleistocene timescale based on ODP Site 677. Trans. R. Soc. Edinburgh, Earth Sci., 81:251-261.

Shipboard Scientific Party, 1992. Site 847. In Mayer, L., Pisias, N., Janecek, T., et al., Proc. ODP, Init. Repts., 138 (Pt. 1): College Station, TX (Ocean Drilling Program), 335-393.

Thompson, P.R., 1976. Planktonic foraminiferal dissolution and the progress towards a Pleistocene equatorial Pacific transfer function. J. Foraminiferal Res., 6:208-227.

Toggweiler, J.R., Dixon, K., and Broecker, W.S., 1991. The Peru upwelling and the ventilation of the south Pacific thermocline. J. Geophys. Res., 96:20467-20497.

Tsuchiya, M., Lukas, R., Fine, R.A., Firing, E., and Lindstrom, E., 1990. Source waters of the Pacific equatorial undercurrent. Progr. Oceanogr., 23:101-147.

Wyrtki, K., 1966. Oceanography of the eastern equatorial Pacific Ocean. Oceanogr. Mar. Biol. Ann. Rev., 4:33-68.

, 1971. Oceanographic Atlas of the International Indian Ocean Expedition. Nat. Sci. Found.

1974a. Equatorial currents in the Pacific 1950-1970 and their relations to Trade Winds. J. Phys. Oceanogr., 4:372-380.

, 1974b. Sea level and the seasonal fluctuations of the equatorial currents in the Western Pacific Ocean. J. Phys. Oceanogr., 4:91-103. , 1981. An estimate of equatorial upwelling in the Pacific. J. Phys. Oceanogr., 11:1205-1214

Date of initial receipt: 28 May 1993

Date of acceptance: 8 March 1994

Ms 138SR-141 


\section{FACTOR 1}
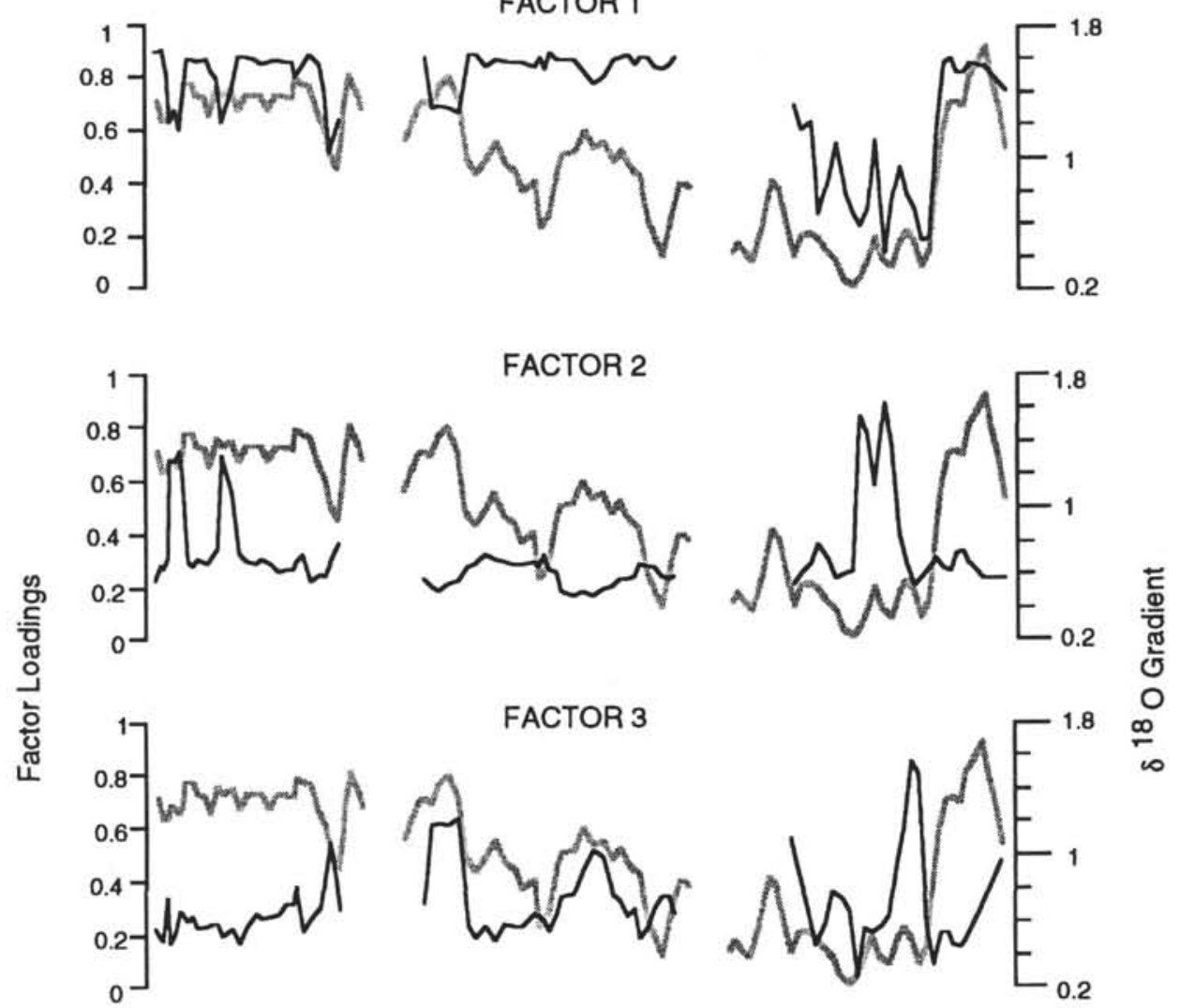

FACTOR 4

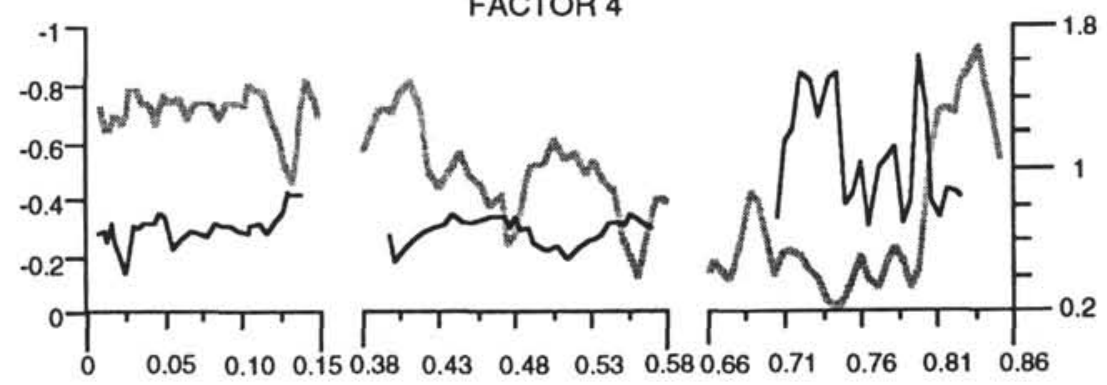

Age (Ma)

Figure 11. Factor loadings are compared to the oxygen isotope gradient between $N$. dutertrei and $G$. sacculifer (Farrell et al., this volume). The black line represents the factor loading, and the gray line represents the isotope gradient. 
APPENDIX

Planktonic Foraminifer Percentages, Sample Information, and Selected Dissolution Indexes for the Composite Record of Site 847.

\begin{tabular}{|c|c|c|c|c|c|c|c|c|c|c|c|c|c|c|c|c|}
\hline $\begin{array}{l}\text { Core, section, } \\
\text { interval (cm) }\end{array}$ & $\begin{array}{l}\text { ODP } \\
\text { depth } \\
\text { (mbsf) }\end{array}$ & $\begin{array}{c}\text { This study } \\
\text { composite depth } \\
\text { (Bmcd) }\end{array}$ & $\begin{array}{l}\text { Age } \\
\text { (Ma) }\end{array}$ & $\begin{array}{c}o \text {. } \\
\text { univ. }\end{array}$ & $\begin{array}{c}G . \\
\text { cglob. }\end{array}$ & $\begin{array}{l}G . \\
\text { ruber } \\
\text { (pink) }\end{array}$ & $\begin{array}{c}G . \\
\text { ruber } \\
\text { (white) }\end{array}$ & $\begin{array}{l}G . \\
\text { enel. }\end{array}$ & $\begin{array}{c}G . \\
\text { sacc. } \\
\text { (w/o sack) }\end{array}$ & $\begin{array}{c}G . \\
\text { sacc. } \\
\text { (with sack) }\end{array}$ & $\underset{\text { dehis. }}{S .}$ & $\begin{array}{c}G . \\
\text { aequi. }\end{array}$ & $\begin{array}{c}G . \\
\text { calid. }\end{array}$ & $\begin{array}{c}G \text {. } \\
\text { bullo. }\end{array}$ & $\begin{array}{c}G . \\
\text { falco. }\end{array}$ & $\begin{array}{c}G . \\
\text { digit. }\end{array}$ \\
\hline \multicolumn{17}{|c|}{$* * * *$ Time Slice $\mathrm{I}^{* * * *}$} \\
\hline 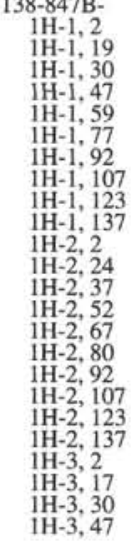 & $\begin{array}{l}0.02 \\
0.19 \\
0.30 \\
0.47 \\
0.59 \\
0.77 \\
0.92 \\
1.07 \\
1.23 \\
1.37 \\
1.52 \\
1.74 \\
1.87 \\
2.02 \\
2.17 \\
2.30 \\
2.42 \\
2.47 \\
2.57 \\
2.73 \\
3.87 \\
3.02 \\
3.17 \\
3.47\end{array}$ & $\begin{array}{l}0.02 \\
0.19 \\
0.30 \\
0.47 \\
0.59 \\
0.77 \\
0.92 \\
1.07 \\
1.23 \\
1.37 \\
1.52 \\
1.74 \\
1.87 \\
2.07 \\
2.17 \\
2.30 \\
2.42 \\
2.47 \\
2 . .73 \\
2.87 \\
3.02 \\
3.17 \\
3.30 \\
3.47\end{array}$ & $\begin{array}{l}0.006 \\
0.009 \\
0.012 \\
0.015 \\
0.017 \\
0.020 \\
0.023 \\
0.025 \\
0.028 \\
0.032 \\
0.036 \\
0.042 \\
0.049 \\
0.049 \\
0.059 \\
0.065 \\
0.070 \\
0.075 \\
0.080 \\
0.085 \\
0.091 \\
0.1096\end{array}$ & $\begin{array}{l}0.63 \\
0.00 \\
0.28 \\
1.47 \\
0.66 \\
1.12 \\
1.56 \\
0.52 \\
0.82 \\
1.66 \\
0.20 \\
1.20 \\
0.96 \\
0.99 \\
0.23 \\
1.83 \\
0.62 \\
0.83 \\
0.71 \\
0.26 \\
0.98 \\
0.83\end{array}$ & $\begin{array}{l}0.00 \\
0.00 \\
0.28 \\
0.00 \\
0.22 \\
0.00 \\
0.00 \\
0.00 \\
0.41 \\
0.00 \\
0.20 \\
0.00 \\
0.00 \\
0.00 \\
0.00 \\
0.00 \\
0.00 \\
0.00 \\
0.00 \\
0.00 \\
0.00 \\
0.00 \\
0.00\end{array}$ & $\begin{array}{l}0.00 \\
0.00 \\
0.00 \\
0.00 \\
0.00 \\
0.00 \\
0.00 \\
0.00 \\
0.00 \\
0.00 \\
0.00 \\
0.00 \\
0.00 \\
0.00 \\
0.00 \\
0.00 \\
0.00 \\
0.00 \\
0.00 \\
0.00 \\
0.00 \\
0.00\end{array}$ & $\begin{array}{l}2.11 \\
3.29 \\
5.85 \\
5.15 \\
2.41 \\
4.91 \\
4.00 \\
4.38 \\
3.07 \\
3.11 \\
3.76 \\
3.79 \\
3.47 \\
4.20 \\
3.00 \\
3.45 \\
1.83 \\
5.30 \\
2.49 \\
7.33 \\
2.87 \\
4.90 \\
4.21 \\
4.99\end{array}$ & $\begin{array}{l}0.00 \\
0.25 \\
0.28 \\
0.37 \\
0.22 \\
0.00 \\
0.00 \\
0.00 \\
0.20 \\
0.00 \\
0.40 \\
0.00 \\
0.00 \\
0.00 \\
0.00 \\
0.00 \\
0.00 \\
0.00 \\
0.00 \\
0.00 \\
0.00 \\
0.00 \\
0.00 \\
0.00\end{array}$ & $\begin{array}{l}1.69 \\
1.77 \\
1.95 \\
3.31 \\
0.44 \\
0.22 \\
0.44 \\
0.00 \\
1.23 \\
0.00 \\
0.00 \\
0.34 \\
0.19 \\
0.25 \\
0.23 \\
0.25 \\
0.31 \\
0.62 \\
0.55 \\
0.47 \\
0.26 \\
0.00 \\
0.65 \\
2.22\end{array}$ & $\begin{array}{l}1.27 \\
1.27 \\
1.39 \\
1.10 \\
0.66 \\
0.22 \\
0.22 \\
0.00 \\
0.61 \\
0.21 \\
0.00 \\
0.69 \\
0.00 \\
0.49 \\
0.00 \\
0.49 \\
0.61 \\
0.00 \\
1.39 \\
1.18 \\
0.04 \\
0.00 \\
0.32\end{array}$ & $\begin{array}{l}0.00 \\
0.00 \\
0.56 \\
0.00 \\
0.00 \\
0.00 \\
0.00 \\
0.00 \\
0.00 \\
0.00 \\
0.00 \\
0.17 \\
0.00 \\
0.00 \\
0.00 \\
0.00 \\
0.00 \\
0.00 \\
0.00 \\
0.24 \\
0.00 \\
0.00\end{array}$ & $\begin{array}{l}0.63 \\
1.27 \\
1.11 \\
0.37 \\
0.66 \\
0.22 \\
0.89 \\
0.52 \\
1.02 \\
0.62 \\
0.59 \\
0.52 \\
0.58 \\
0.99 \\
0.46 \\
0.25 \\
0.31 \\
0.00 \\
0.55 \\
1.42 \\
0.52 \\
0.49 \\
0.65 \\
0.55\end{array}$ & $\begin{array}{l}0.00 \\
0.51 \\
1.39 \\
0.74 \\
0.66 \\
0.22 \\
0.22 \\
0.26 \\
1.23 \\
0.41 \\
0.79 \\
0.52 \\
1.73 \\
1.23 \\
0.00 \\
0.49 \\
0.00 \\
0.93 \\
1.66 \\
0.95 \\
1.31 \\
0.49 \\
0.97 \\
0.28\end{array}$ & 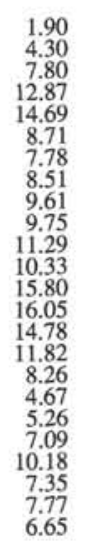 & $\begin{array}{l}0.00 \\
0.25 \\
1.95 \\
0.00 \\
1.32 \\
0.22 \\
1.33 \\
0.00 \\
0.20 \\
0.62 \\
0.59 \\
0.52 \\
0.77 \\
0.99 \\
0.23 \\
0.25 \\
1.83 \\
0.93 \\
0.55 \\
0.24 \\
0.00 \\
0.98 \\
0.32 \\
0.83\end{array}$ & $\begin{array}{l}1.06 \\
0.25 \\
0.00 \\
0.00 \\
0.44 \\
0.00 \\
0.00 \\
0.52 \\
0.41 \\
0.41 \\
0.20 \\
0.00 \\
0.00 \\
0.25 \\
0.23 \\
0.74 \\
0.00 \\
0.31 \\
0.00 \\
0.00 \\
0.26 \\
0.97 \\
0.28\end{array}$ \\
\hline $\begin{array}{l}38-847 \mathrm{C}- \\
1 \mathrm{H}-1,22 \\
1 \mathrm{H}-1,137 \\
1 \mathrm{H}-2,2 \\
1 \mathrm{H}-2,17 \\
1 \mathrm{H}-2,32 \\
1 \mathrm{H}-2,47 \\
1 \mathrm{H}-2,77\end{array}$ & $\begin{array}{l}3.22 \\
3.37 \\
3.52 \\
3.67 \\
3.82 \\
3.97 \\
4.27\end{array}$ & $\begin{array}{l}3.50 \\
3.65 \\
3.80 \\
3.95 \\
4.10 \\
4.25 \\
4.55\end{array}$ & $\begin{array}{l}0.103 \\
0.108 \\
0.114 \\
0.119 \\
0.124 \\
0.128 \\
0.135\end{array}$ & $\begin{array}{l}0.70 \\
0.20 \\
0.95 \\
0.59 \\
0.65 \\
1.03 \\
0.46\end{array}$ & $\begin{array}{l}0.47 \\
0.20 \\
0.00 \\
0.00 \\
0.00 \\
0.00 \\
0.00\end{array}$ & $\begin{array}{l}0.00 \\
0.00 \\
0.00 \\
0.00 \\
0.33 \\
3.10 \\
0.46\end{array}$ & $\begin{array}{r}9.07 \\
6.32 \\
2.85 \\
6.82 \\
9.45 \\
11.38 \\
3.69\end{array}$ & $\begin{array}{l}0.23 \\
0.00 \\
0.00 \\
0.30 \\
0.00 \\
0.00 \\
0.31\end{array}$ & $\begin{array}{l}1.63 \\
1.78 \\
1.14 \\
2.37 \\
3.26 \\
3.45 \\
1.54\end{array}$ & $\begin{array}{l}2.09 \\
1.58 \\
0.76 \\
0.89 \\
3.26 \\
1.72 \\
1.08\end{array}$ & & $\begin{array}{l}1.16 \\
1.19 \\
0.57 \\
0.30 \\
1.95 \\
2.41 \\
1.23\end{array}$ & $\begin{array}{l}0.93 \\
0.20 \\
0.76 \\
0.89 \\
1.63 \\
1.90 \\
0.77\end{array}$ & $\begin{array}{r}7.91 \\
8.30 \\
5.13 \\
7.72 \\
8.47 \\
19.83 \\
27.69\end{array}$ & $\begin{array}{l}0.23 \\
0.00 \\
0.19 \\
0.59 \\
0.65 \\
1.21 \\
0.92\end{array}$ & $\begin{array}{l}0.47 \\
0.40 \\
0.38 \\
0.00 \\
0.65 \\
0.69 \\
0.62\end{array}$ \\
\hline 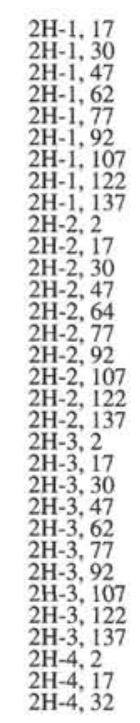 & $\begin{array}{l}11.67 \\
11.80 \\
11.97 \\
12.12 \\
12.27 \\
12.42 \\
12.57 \\
12.72 \\
12.87 \\
13.02 \\
13.17 \\
13.30 \\
13.47 \\
13.64 \\
13.77 \\
13.92 \\
14.07 \\
14.22 \\
14.37 \\
11.52 \\
14.67 \\
14.80 \\
14.97 \\
15.12 \\
15.27 \\
15.42 \\
15.57 \\
15.72 \\
15.87 \\
16.02 \\
11.17 \\
16.32\end{array}$ & $\begin{array}{l}13.08 \\
13.21 \\
13.38 \\
13.53 \\
13.68 \\
13.83 \\
13.98 \\
14.13 \\
14.28 \\
14.43 \\
14.58 \\
14.71 \\
14.88 \\
15.05 \\
15.18 \\
15.33 \\
15.48 \\
15.63 \\
15.78 \\
15.93 \\
16.08 \\
16.21 \\
16.38 \\
16.53 \\
16.68 \\
16.83 \\
16.98 \\
17.13 \\
17.28 \\
17.43 \\
17.58 \\
17.73\end{array}$ & $\begin{array}{l}0.395 \\
0.399 \\
0.405 \\
0.411 \\
0.418 \\
0.424 \\
0.431 \\
0.437 \\
0.444 \\
0.451 \\
0.458 \\
0.463 \\
0.471 \\
0.475 \\
0.478 \\
0.482 \\
0.487 \\
0.491 \\
0.498 \\
0.506 \\
0.520 \\
0.527 \\
0.532 \\
0.536 \\
0.541 \\
0.546 \\
0.551 \\
0.555 \\
0.565 \\
0.569\end{array}$ & $\begin{array}{l}0.79 \\
0.80 \\
0.75 \\
0.77 \\
0.77 \\
1.35 \\
1.06 \\
1.36 \\
2.14 \\
1.13 \\
1.48 \\
3.42 \\
2.24 \\
2.10 \\
1.39 \\
0.97 \\
0.28 \\
0.32 \\
0.49 \\
1.33 \\
1.82 \\
2.11 \\
0.60 \\
2.65 \\
0.71 \\
1.00 \\
1.00 \\
4.22 \\
4.71 \\
3.63 \\
2.66\end{array}$ & $\begin{array}{l}0.00 \\
0.27 \\
0.00 \\
0.77 \\
0.38 \\
0.19 \\
0.35 \\
0.27 \\
0.00 \\
0.00 \\
0.00 \\
0.00 \\
0.00 \\
0.00 \\
0.00 \\
0.00 \\
0.00 \\
0.00 \\
0.00 \\
0.00 \\
0.26 \\
0.00 \\
0.00 \\
0.00 \\
1.00 \\
0.00 \\
0.00 \\
0.00 \\
0.00 \\
0.00 \\
0.00\end{array}$ & $\begin{array}{l}0.26 \\
0.00 \\
0.25 \\
0.00 \\
1.15 \\
0.00 \\
0.00 \\
0.00 \\
0.00 \\
0.00 \\
0.00 \\
0.00 \\
0.00 \\
0.35 \\
0.00 \\
0.57 \\
0.00 \\
0.00 \\
0.52 \\
0.00 \\
0.00 \\
0.00 \\
1.00 \\
0.00 \\
0.30 \\
0.00 \\
0.39 \\
0.06 \\
.00\end{array}$ & $\begin{array}{l}2.63 \\
3.18 \\
4.25 \\
4.62 \\
6.92 \\
2.69 \\
4.24 \\
5.42 \\
3.56 \\
4.24 \\
4.93 \\
2.40 \\
4.15 \\
2.89 \\
3.48 \\
2.27 \\
2.27 \\
1.27 \\
0.25 \\
4.67 \\
3.39 \\
5.80 \\
3.59 \\
3.24 \\
6.53 \\
.35 \\
4.80 \\
5.95 \\
5.01 \\
4.10 \\
4.62 \\
4.98\end{array}$ & $\begin{array}{l}2 * 00 \\
0.00 \\
0.53 \\
0.50 \\
1.54 \\
1.54 \\
0.58 \\
0.35 \\
0.27 \\
0.36 \\
0.00 \\
0.00 \\
0.34 \\
0.00 \\
0.00 \\
0.70 \\
0.00 \\
0.00 \\
0.00 \\
0.00 \\
0.33 \\
0.00 \\
0.53 \\
0.00 \\
0.29 \\
0.00 \\
0.00 \\
0.00 \\
0.61 \\
0.29 \\
0.00 \\
0.606 \\
0.00\end{array}$ & $\begin{array}{l}1.05 \\
3.18 \\
3.50 \\
3.33 \\
1.54 \\
0.58 \\
1.06 \\
1.63 \\
3.91 \\
1.98 \\
3.20 \\
1.71 \\
1.28 \\
1.05 \\
0.70 \\
1.30 \\
1.70 \\
0.32 \\
0.49 \\
3.33 \\
0.52 \\
1.85 \\
0.60 \\
0.00 \\
1.77 \\
4.01 \\
0.60 \\
1.52 \\
2.95 \\
1.96 \\
2.31 \\
1.33\end{array}$ & $\begin{array}{l}0.26 \\
0.53 \\
2.25 \\
1.54 \\
0.96 \\
0.96 \\
0.71 \\
0.81 \\
0.36 \\
1.13 \\
1.97 \\
3.08 \\
0.96 \\
0.26 \\
0.70 \\
0.00 \\
1.13 \\
0.32 \\
0.00 \\
0.33 \\
1.04 \\
2.64 \\
1.50 \\
0.59 \\
1.41 \\
2.34 \\
1.20 \\
0.61 \\
2.06 \\
2.35 \\
2.31 \\
2.33\end{array}$ & $\begin{array}{l}0.00 \\
0.00 \\
0.00 \\
0.00 \\
0.00 \\
0.00 \\
0.00 \\
0.00 \\
0.00 \\
0.00 \\
0.00 \\
0.00 \\
0.00 \\
0.00 \\
0.00 \\
0.32 \\
0.25 \\
0.07 \\
0.00 \\
0.00 \\
0.00 \\
0.00 \\
0.00 \\
0.00 \\
0.00\end{array}$ & $\begin{array}{l}0.53 \\
0.27 \\
1.25 \\
1.03 \\
1.15 \\
0.00 \\
0.71 \\
0.00 \\
0.00 \\
0.56 \\
0.25 \\
0.34 \\
1.60 \\
0.26 \\
0.00 \\
0.65 \\
0.00 \\
0.32 \\
0.00 \\
2.00 \\
1.04 \\
0.79 \\
0.00 \\
0.29 \\
0.71 \\
3.01 \\
1.82 \\
0.59 \\
0.39 \\
0.33 \\
1.66\end{array}$ & $\begin{array}{l}0.53 \\
1.33 \\
0.25 \\
1.54 \\
1.35 \\
0.58 \\
0.35 \\
0.54 \\
0.00 \\
0.00 \\
0.25 \\
0.68 \\
0.64 \\
0.00 \\
0.70 \\
0.00 \\
0.00 \\
0.32 \\
0.00 \\
0.67 \\
0.52 \\
0.26 \\
0.90 \\
0.00 \\
0.35 \\
0.67 \\
0.60 \\
0.61 \\
1.77 \\
2.75 \\
0.00 \\
0.66\end{array}$ & $\begin{array}{l}5.53 \\
5.84 \\
7.50 \\
9.49 \\
9.81 \\
6.15 \\
4.95 \\
9.76 \\
4.27 \\
5.37 \\
7.64 \\
9.93 \\
8.95 \\
6.04 \\
10.45 \\
4.55 \\
3.40 \\
3.18 \\
0.49 \\
2.00 \\
2.60 \\
1.85 \\
2.10 \\
0.88 \\
0.00 \\
2.01 \\
4.50 \\
4.56 \\
6.49 \\
9.02 \\
5.94 \\
3.65\end{array}$ & $\begin{array}{l}1.58 \\
0.00 \\
0.25 \\
0.77 \\
0.96 \\
1.15 \\
0.71 \\
0.54 \\
0.36 \\
1.13 \\
0.00 \\
0.00 \\
0.00 \\
0.00 \\
0.35 \\
0.32 \\
0.28 \\
0.32 \\
0.00 \\
0.67 \\
0.52 \\
0.00 \\
0.30 \\
0.00 \\
0.00 \\
0.00 \\
0.60 \\
0.00 \\
0.00 \\
1.57 \\
0.00 \\
0.00\end{array}$ & $\begin{array}{l}0.00 \\
0.53 \\
1.00 \\
0.26 \\
1.15 \\
0.38 \\
0.35 \\
0.54 \\
0.36 \\
0.00 \\
0.00 \\
0.00 \\
0.00 \\
0.26 \\
0.35 \\
0.00 \\
0.00 \\
0.64 \\
0.49 \\
0.00 \\
0.00 \\
0.26 \\
0.60 \\
0.00 \\
0.35 \\
0.00 \\
0.00 \\
0.00 \\
0.00 \\
0.00 \\
0.00 \\
0.00\end{array}$ \\
\hline $\begin{array}{l}2 \mathrm{H}-6,107 \\
2 \mathrm{H}-6,6,122 \\
2 \mathrm{H}-6,137 \\
2 \mathrm{H}-7,2 \\
2 \mathrm{H}-7,17 \\
2 \mathrm{H}-7,30\end{array}$ & $\begin{array}{l}20.07 \\
20.22 \\
20.37 \\
20.52 \\
20.67 \\
20.80\end{array}$ & $\begin{array}{l}21.48 \\
21.63 \\
21.78 \\
21.93 \\
22.08 \\
22.21\end{array}$ & $\begin{array}{l}0.704 \\
0.709 \\
0.715 \\
0.720 \\
0.726 \\
0.732\end{array}$ & $\begin{array}{l}4.21 \\
2.46 \\
1.85 \\
1.48 \\
2.88 \\
2.20\end{array}$ & $\begin{array}{l}0.00 \\
0.27 \\
0.31 \\
0.30 \\
0.22 \\
0.00\end{array}$ & $\begin{array}{l}0.3 \\
1.3 \\
0.9 \\
0.0 \\
0.0 \\
0.0\end{array}$ & $\begin{array}{l}9.29 \\
4.01 \\
2.66 \\
5.10 \\
7.25\end{array}$ & & $\begin{array}{l}4.53 \\
4.92 \\
1.23 \\
2.37 \\
2.66 \\
2.20\end{array}$ & $\begin{array}{l}4.10 \\
0.62 \\
0.59 \\
0.67 \\
3.08\end{array}$ & & $\begin{array}{l}2.27 \\
1.37 \\
0.31 \\
0.00 \\
1.11 \\
0.88\end{array}$ & $\begin{array}{l}2.27 \\
0.27 \\
1.23 \\
0.89 \\
0.44 \\
1.10\end{array}$ & $\begin{array}{r}2.91 \\
7.10 \\
8.95 \\
21.60 \\
12.86 \\
6.37\end{array}$ & $\begin{array}{l}1.29 \\
1.37 \\
2.16 \\
0.89 \\
0.44 \\
0.44\end{array}$ & $\begin{array}{l}0.32 \\
0.00 \\
0.93 \\
0.00 \\
0.22 \\
0.66\end{array}$ \\
\hline $\begin{array}{l}\text { 138-847D- } \\
3 \mathrm{H}-3,62 \\
3 \mathrm{H}-3,77 \\
3 \mathrm{H}-3,92 \\
3 \mathrm{H}-3,107 \\
3 \mathrm{H}-3,122 \\
3 \mathrm{H}-3,137\end{array}$ & $\begin{array}{l}19.72 \\
19.87 \\
220.02 \\
20.17 \\
20.32 \\
20.47\end{array}$ & $\begin{array}{l}22.38 \\
22.53 \\
22.68 \\
22.83 \\
22.98 \\
23.13\end{array}$ & $\begin{array}{l}0.739 \\
0.744 \\
0.750 \\
0.755 \\
0.761 \\
0.766\end{array}$ & $\begin{array}{l}3.87 \\
1.99 \\
0.35 \\
1.66 \\
2.96 \\
2.00\end{array}$ & $\begin{array}{l}0.30 \\
0.33 \\
0.35 \\
0.00 \\
0.00 \\
0.00\end{array}$ & $\begin{array}{l}0.6 \\
0.6 \\
0.6 \\
0.6\end{array}$ & $\begin{array}{r}8.63 \\
12.25 \\
4.96 \\
8.03 \\
5.33 \\
6.86\end{array}$ & & $\begin{array}{l}4.97 \\
0.71 \\
2.77 \\
3.25 \\
1.43\end{array}$ & $\begin{array}{l}1.99 \\
2.48 \\
2.49 \\
2.66 \\
2.86\end{array}$ & 0.00 & $\begin{array}{l}0.30 \\
1.66 \\
0.71 \\
0.83 \\
0.59 \\
0.86\end{array}$ & $\begin{array}{l}0.89 \\
1.32 \\
0.71 \\
0.00 \\
0.59 \\
0.57\end{array}$ & $\begin{array}{l}9.82 \\
4.30 \\
1.77 \\
5.54 \\
6.80 \\
8.86\end{array}$ & $\begin{array}{l}0.00 \\
0.33 \\
0.35 \\
0.55 \\
0.30 \\
0.00\end{array}$ & $\begin{array}{l}0.00 \\
0.00 \\
0.00 \\
0.00 \\
0.00 \\
0.00\end{array}$ \\
\hline $\begin{array}{l}38-847 \mathrm{C}-17 \\
3 \mathrm{H}-1,17 \\
3 \mathrm{H}-1,32 \\
3 \mathrm{H}-1,47 \\
3 \mathrm{H}-1,62 \\
3 \mathrm{H}-1,77 \\
3 \mathrm{H}-1,92 \\
3 \mathrm{H}-1,107 \\
3 \mathrm{H}-1,122 \\
3 \mathrm{H}-1,1,137 \\
3 \mathrm{H}-2,2 \\
3 \mathrm{H}-2,17 \\
3 \mathrm{H}-2,30 \\
3 \mathrm{H}-2,65 \\
3 \mathrm{H}-2,107\end{array}$ & $\begin{array}{l}21.17 \\
21.32 \\
21.47 \\
21.62 \\
21.77 \\
21.92 \\
22.07 \\
22.22 \\
22.37 \\
22.52 \\
22.67 \\
22.80 \\
23.15 \\
23.57\end{array}$ & 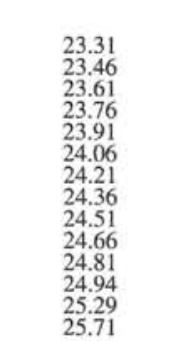 & $\begin{array}{l}0.772 \\
0.778 \\
0.788 \\
0.793 \\
0.798 \\
0.803 \\
0.808 \\
0.812 \\
0.817 \\
0.822 \\
0.826 \\
0.837 \\
0.851\end{array}$ & $\begin{array}{l}2.39 \\
2.75 \\
4.42 \\
5.85 \\
5.02 \\
1.57 \\
1.60 \\
0.63 \\
2.62 \\
1.38 \\
0.68 \\
1.45 \\
1.99\end{array}$ & $\begin{array}{l}0.00 \\
0.00 \\
0.32 \\
1.42 \\
0.36 \\
0.00 \\
0.00 \\
0.00 \\
0.00 \\
0.00 \\
0.00 \\
0.23 \\
0.36 \\
0.00\end{array}$ & $\begin{array}{l}0.27 \\
1.53 \\
0.32 \\
0.28 \\
0.36 \\
0.00 \\
0.00 \\
0.00 \\
0.00 \\
0.33 \\
0.00 \\
0.00 \\
1.24\end{array}$ & $\begin{array}{r}7.16 \\
13.15 \\
12.62 \\
15.38 \\
16.49 \\
7.71 \\
4.88 \\
2.88 \\
4.13 \\
4.26 \\
4.42 \\
4.54 \\
1.82 \\
7.71\end{array}$ & $\begin{array}{l}0.95 \\
0.57 \\
1.08 \\
0.29 \\
0.00 \\
0.00 \\
0.00 \\
0.33 \\
0.00 \\
0.00 \\
0.36 \\
0.00\end{array}$ & $\begin{array}{l}2.75 \\
4.73 \\
6.84 \\
7.17 \\
3.43 \\
1.03 \\
1.60 \\
2.86 \\
0.66 \\
0.83 \\
0.68 \\
2.55 \\
1.74\end{array}$ & $\begin{array}{l}2.65 \\
1.53 \\
4.42 \\
5.98 \\
5.73 \\
2.57 \\
0.51 \\
0.64 \\
0.63 \\
0.00 \\
0.00 \\
0.45 \\
4.36 \\
1.00\end{array}$ & $\begin{array}{l}0.00 \\
0.32 \\
0.85 \\
0.00 \\
0.00 \\
0.00 \\
0.00 \\
0.00 \\
0.00 \\
0.00\end{array}$ & $\begin{array}{l}0.27 \\
0.61 \\
0.43 \\
1.42 \\
0.36 \\
0.06 \\
0.00 \\
0.00 \\
0.66 \\
0.00 \\
0.00 \\
0.00 \\
1.00\end{array}$ & $\begin{array}{l}0.53 \\
0.31 \\
1.26 \\
1.42 \\
2.15 \\
0.00 \\
0.26 \\
0.32 \\
0.00 \\
0.33 \\
0.83 \\
0.23 \\
0.36 \\
0.25\end{array}$ & $\begin{array}{r}9.81 \\
5.50 \\
16.72 \\
8.55 \\
12.90 \\
21.43 \\
6.17 \\
4.15 \\
2.22 \\
5.25 \\
6.08 \\
4.31 \\
5.82 \\
6.72\end{array}$ & $\begin{array}{l}1.06 \\
2.75 \\
1.89 \\
0.85 \\
1.79 \\
0.00 \\
0.26 \\
0.32 \\
0.32 \\
0.33 \\
0.00 \\
0.00 \\
0.00 \\
1.99\end{array}$ & $\begin{array}{l}0.00 \\
0.00 \\
1.58 \\
0.00 \\
0.00 \\
0.86 \\
0.51 \\
0.00 \\
0.00 \\
0.66 \\
0.00 \\
0.45 \\
0.73 \\
1.00\end{array}$ \\
\hline
\end{tabular}


APPENDIX (continued).

\begin{tabular}{|c|c|c|}
\hline $\begin{array}{c}G . \\
\text { rubes. }\end{array}$ & $\begin{array}{c}G . \\
\text { quinq. }\end{array}$ & $\begin{array}{l}N . \\
\text { pac. } \\
(\mathrm{L})\end{array}$ \\
\hline 138-847B- & & \\
\hline 0.00 & 0.00 & 0.42 \\
\hline 0.00 & 0.00 & 0.00 \\
\hline 0.56 & 0.00 & 0.00 \\
\hline 0.37 & 0.00 & 0.00 \\
\hline 0.00 & 0.00 & 0.44 \\
\hline 0.00 & 0.00 & 0.00 \\
\hline 0.22 & 0.00 & 0.44 \\
\hline 0.77 & 0.26 & 0.26 \\
\hline 0.00 & 0.00 & 0.20 \\
\hline 0.00 & 0.00 & 0.21 \\
\hline 0.20 & 0.00 & 0.20 \\
\hline 0.00 & 0.17 & 0.00 \\
\hline 0.39 & 0.19 & 0.39 \\
\hline 0.49 & 0.00 & 0.49 \\
\hline 0.00 & 0.23 & 0.23 \\
\hline 0.00 & 0.00 & 0.74 \\
\hline 0.31 & 0.00 & 0.00 \\
\hline 0.00 & 0.00 & 0.31 \\
\hline 0.00 & 0.28 & 0.55 \\
\hline 0.71 & 0.00 & 0.24 \\
\hline 0.78 & 0.00 & 0.52 \\
\hline 0.00 & 0.00 & 0.98 \\
\hline 0.00 & 0.00 & 0.32 \\
\hline 1.11 & 0.00 & 0.28 \\
\hline $138-847 \mathrm{C}-$ & & \\
\hline 0.93 & 0.00 & 0.23 \\
\hline 0.59 & 0.00 & 0.40 \\
\hline 0.00 & 0.00 & 0.00 \\
\hline 0.30 & 0.00 & 0.30 \\
\hline 0.33 & 0.33 & 0.00 \\
\hline 1.38 & 0.00 & 0.00 \\
\hline 0.62 & 0.31 & 0.92 \\
\hline & & \\
\hline 0.00 & 0.00 & 0.00 \\
\hline 1.06 & 0.00 & 0.00 \\
\hline 0.25 & 0.00 & 0.00 \\
\hline 0.26 & 0.00 & 0.00 \\
\hline 1.35 & 0.00 & 0.38 \\
\hline 0.58 & 0.00 & 0.00 \\
\hline 0.71 & 0.00 & 0.35 \\
\hline 0.54 & 0.27 & -0.81 \\
\hline 0.36 & 0.00 & 0.71 \\
\hline 0.28 & 0.00 & 0.85 \\
\hline 0.00 & 0.25 & 0.49 \\
\hline 0.00 & 0.00 & 0.34 \\
\hline 0.64 & 0.64 & 0.64 \\
\hline 0.00 & 0.52 & 0.26 \\
\hline 0.00 & 0.00 & 1.05 \\
\hline 0.00 & 0.00 & 0.65 \\
\hline 0.00 & 0.28 & 1.42 \\
\hline 0.00 & 0.00 & 0.00 \\
\hline 0.00 & 0.00 & 0.00 \\
\hline 0.00 & 0.00 & 0.00 \\
\hline 0.26 & 0.00 & 0.00 \\
\hline 0.00 & 0.00 & 0.00 \\
\hline 0.00 & 0.00 & 0.30 \\
\hline 0.00 & 0.29 & 0.88 \\
\hline 0.00 & 0.00 & 0.35 \\
\hline 0.33 & 0.33 & 0.67 \\
\hline 0.00 & 0.60 & 0.00 \\
\hline 0.30 & 0.30 & 0.61 \\
\hline 0.00 & 0.29 & 0.88 \\
\hline 0.78 & 0.00 & 0.00 \\
\hline 0.00 & 0.33 & 0.33 \\
\hline 0.33 & 0.33 & 0.00 \\
\hline & & \\
\hline 1.29 & 0.00 & 0.65 \\
\hline 0.55 & 0.00 & 10.93 \\
\hline 0.62 & 0.00 & 15.43 \\
\hline 0.00 & 0.00 & 23.96 \\
\hline 0.00 & 0.44 & 20.62 \\
\hline 0.22 & 0.00 & 19.34 \\
\hline $138-847 \mathrm{D}-$ & & \\
\hline 0.30 & 0.00 & 23.51 \\
\hline 0.00 & 0.33 & 25.83 \\
\hline 0.00 & 0.00 & 14.54 \\
\hline 0.00 & 0.28 & 9.42 \\
\hline 0.00 & 0.30 & 10.65 \\
\hline 0.00 & 1.14 & 10.86 \\
\hline $138-847 \mathrm{C}-$ & & \\
\hline 0.00 & 0.27 & 13.26 \\
\hline 0.92 & & \\
\hline 0.32 & 0.00 & 5.99 \\
\hline 0.28 & 0.00 & 0.28 \\
\hline 1.08 & 0.00 & 0.36 \\
\hline 0.00 & 0.29 & 27.43 \\
\hline 0.26 & 0.00 & 23.91 \\
\hline 0.00 & 0.00 & 5.43 \\
\hline 0.00 & 0.00 & 2.54 \\
\hline 0.00 & 0.98 & 6.89 \\
\hline 0.00 & 0.00 & 6.35 \\
\hline 0.00 & 0.00 & 7.03 \\
\hline 0.36 & 0.36 & 2.91 \\
\hline & 0.00 & 4.23 \\
\hline
\end{tabular}


APPENDIX (continued).

\begin{tabular}{|c|c|c|c|c|c|c|c|c|c|}
\hline $\begin{array}{l}\text { Core, section } \\
\text { interval }(\mathrm{cm})\end{array}$ & $\begin{array}{c}G . \\
\text { gluti. }\end{array}$ & $\begin{array}{c}G . \\
\text { theyr. }\end{array}$ & Other & $\begin{array}{l}\text { Foram. } \\
\text { per } \\
\text { sample }\end{array}$ & $\begin{array}{c}\text { Whole } \\
\text { planktonic } \\
(\%)\end{array}$ & $\begin{array}{c}\text { Linear } \\
\text { sed. rate } \\
(\mathrm{m} / \mathrm{Ma})\end{array}$ & $\begin{array}{c}\text { Dry-bulk } \\
\text { density } \\
\left(\mathrm{g} / \mathrm{cm}^{3)}\right.\end{array}$ & Split & $\begin{array}{c}\text { Sample } \\
\text { weight } \\
\text { (g) }\end{array}$ \\
\hline $138-847 \mathrm{~B}-$ & & & & & *** > & ime Slice 1 & ***** & & \\
\hline $1 \mathrm{H}-1,2$ & 1.69 & 0.00 & 0.00 & 473 & 54.75 & 50.77 & 0.36595 & $3 / 64$ & 0.2628 \\
\hline $1 \mathrm{H}-1,19$ & 2.03 & 0.00 & 0.51 & 395 & 57.66 & 50.77 & 0.38903 & $1 / 128$ & 0.0435 \\
\hline $\begin{array}{l}1 \mathrm{H}-1,30 \\
\mathrm{H}-1,47\end{array}$ & 2.51 & 0.00 & 0.28 & 359 & 76.22 & 50.76 & 0.44594 & $1 / 128$ & 0.0328 \\
\hline $\begin{array}{l}1 \mathrm{H}-1,47 \\
1 \mathrm{H}-1,59\end{array}$ & 2.57 & 0.00 & 0.74 & 272 & 74.52 & 50.78 & 0.44747 & $1 / 128$ & 0.0366 \\
\hline & $\begin{array}{l}1.54 \\
2.68\end{array}$ & 0.00 & 1.32 & 456 & 57.65 & 55.45 & 0.40748 & $1 / 64$ & 0.0694 \\
\hline $\begin{array}{l}1 \mathrm{H}-1,77 \\
1 \mathrm{H}-1,92\end{array}$ & $\begin{array}{l}2.68 \\
2.89\end{array}$ & 0.00 & $\begin{array}{l}1.34 \\
0.67\end{array}$ & 448 & $\begin{array}{r}55.10 \\
4808\end{array}$ & 61.12 & $\begin{array}{l}0.43671 \\
0.42594\end{array}$ & $1 / 64$ & 0.0794 \\
\hline $1 \mathrm{H}-1,107$ & 1.03 & 0.00 & 0.77 & 388 & $\begin{array}{l}48.08 \\
68.31\end{array}$ & $\begin{array}{l}01.10 \\
61.12\end{array}$ & $\begin{array}{l}0.42394 \\
0.51515\end{array}$ & $\begin{array}{l}1 / 04 \\
1 / 128\end{array}$ & $\begin{array}{l}0.0817 \\
0.0446\end{array}$ \\
\hline $1 \mathrm{H}-1,123$ & 2.66 & 0.00 & 0.20 & 489 & 58.84 & 37.60 & 0.46439 & $1 / 64$ & 0.1026 \\
\hline $1 \mathrm{H}-1,137$ & 2.49 & 0.00 & 0.00 & 482 & 71.51 & 37.59 & 0.43824 & $\begin{array}{l}1 / 64 \\
1 / 64\end{array}$ & 0.0734 \\
\hline $1 \mathrm{H}-2,2$ & 2.77 & 0.00 & 0.20 & 505 & $\begin{array}{l}66.89 \\
69\end{array}$ & 37.60 & 0.40441 & $1 / 32$ & 0.1404 \\
\hline 1H-2, 24 & 2.24 & 0.00 & 0.00 & 581 & 80.58 & 37.60 & 0.38595 & $1 / 64$ & 0.0687 \\
\hline $1 \mathrm{H}-2,37$ & 2.50 & 0.00 & 0.39 & 519 & 78.76 & 37.59 & 0.38595 & $1 / 64$ & 0.0707 \\
\hline $1 \mathrm{H}-2,52$ & 1.23 & 0.00 & 0.99 & 405 & 79.57 & 37.60 & 0.33673 & $1 / 64$ & 0.0396 \\
\hline $1 \mathrm{H}-2,67$ & 3.23 & 0.00 & 0.69 & 433 & 70.29 & 20.83 & 0.33058 & $1 / 16$ & 0.2070 \\
\hline $1 \mathrm{H}-2,80$ & 1.72 & 0.00 & 0.00 & 406 & 72.63 & 20.83 & 0.2629 & $1 / 16$ & 0.1650 \\
\hline $1 \mathrm{H}-2,92$ & 1.53 & 0.00 & 0.61 & 327 & 52.15 & 30.00 & 0.22137 & $1 / 8$ & 0.3273 \\
\hline $1 \mathrm{H}-2,107$ & 1.87 & 0.00 & 0.31 & 321 & 60.23 & 30.00 & 0.26905 & $1 / 16$ & 0.1756 \\
\hline $\begin{array}{l}1 \mathrm{H}-2,123 \\
1 \mathrm{H}-2,137\end{array}$ & 2.49 & 0.00 & 0.55 & 361 & 54.61 & 30.00 & 0.33365 & $1 / 32$ & 0.1244 \\
\hline $\begin{array}{l}1 \mathrm{H}-2,137 \\
1 \mathrm{H}-3,2\end{array}$ & $\begin{array}{l}4.73 \\
2.09\end{array}$ & 0.00 & 0.47 & 423 & 71.82 & 27.50 & 0.30904 & & \\
\hline $\begin{array}{l}1 \mathrm{H}-3,2 \\
1 \mathrm{H}-3,17\end{array}$ & $\begin{array}{l}2.09 \\
1.47\end{array}$ & 0.52 & 1.04 & 383 & 66.84 & 27.50 & 0.29674 & $\begin{array}{l}3 / 32 \\
3 / 16\end{array}$ & 0.3124 \\
\hline $\begin{array}{l}1 \mathrm{H}-3,17 \\
1 \mathrm{H}-3,30\end{array}$ & $\begin{array}{l}1.47 \\
2.27\end{array}$ & $\begin{array}{l}0.00 \\
1.94\end{array}$ & 0.49 & $\begin{array}{l}204 \\
309\end{array}$ & $\begin{array}{l}51.78 \\
49902\end{array}$ & $\begin{array}{l}27.50 \\
27.49\end{array}$ & $\begin{array}{l}0.27059 \\
028905\end{array}$ & $3 / 16$ & 0.5606 \\
\hline $1 \mathrm{H}-3,47$ & 1.94 & 0.55 & 0.28 & 361 & 62.13 & 27.52 & 0.33981 & $\mathrm{~N} / \mathrm{A}$ & \\
\hline $138-847 \mathrm{C}$ - & & & & & & & & & \\
\hline $1 \mathrm{H}-1,122$ & & 0.47 & 0.93 & 430 & 69.13 & 27.52 & 0.33365 & $1 / 32$ & 0.1509 \\
\hline $\begin{array}{l}\mathrm{H}-1,137 \\
\mathrm{H}-2\end{array}$ & 1.38 & 0.40 & 0.59 & 506 & 66.49 & 27.47 & 0.29828 & $1 / 16$ & 0.1874 \\
\hline $\begin{array}{l}1 \mathrm{H}-2,2 \\
1 \mathrm{H}-2,17\end{array}$ & $\begin{array}{l}1.71 \\
4.75\end{array}$ & 0.00 & 0.00 & $\begin{array}{l}526 \\
337\end{array}$ & $\begin{array}{l}46.88 \\
55.52\end{array}$ & 27.52 & 0.2183 & $1 / 8$ & 0.3784 \\
\hline $1 \mathrm{H}-2,32$ & 12.05 & 0.00 & $\begin{array}{l}0.89 \\
0.65\end{array}$ & 307 & 52.21 & $\begin{array}{l}32.68 \\
40.43\end{array}$ & $\begin{array}{l}0.38281 \\
0.39056\end{array}$ & $\begin{array}{l}1 / 16 \\
1 / 32\end{array}$ & $\begin{array}{l}0.2383 \\
0.1049\end{array}$ \\
\hline $1 \mathrm{H}-2,47$ & 11.72 & 0.00 & 1.90 & 580 & 67.84 & $\begin{array}{l}40.43 \\
40.36\end{array}$ & 0.37826 & $1 / 16$ & 0.1993 \\
\hline $1 \mathrm{H}-2,77$ & 3.54 & 0.00 & 1.85 & 650 & 74.88 & 46.88 & 0.42748 & $1 / 16$ & 0.2483 \\
\hline & & & & & & ne Slice 2 & $* * * *$ & & \\
\hline & & 0.00 & 0.79 & 380 & & & & $1 / 16$ & \\
\hline $2 \mathrm{H}-1,30$ & 5.04 & 0.00 & 0.00 & $\begin{array}{l}380 \\
377\end{array}$ & $\begin{array}{l}64.89 \\
6417\end{array}$ & $\begin{array}{l}28.90 \\
29.01\end{array}$ & 0.61513 & $\begin{array}{l}1110 \\
3 / 32\end{array}$ & 0.5620 \\
\hline $2 \mathrm{H}-1,47$ & 6.25 & 0.00 & 0.50 & 400 & 72.60 & 23.29 & 0.58283 & $3 / 64$ & 0.2922 \\
\hline $2 \mathrm{H}-1,62$ & 7.18 & 0.00 & 0.26 & 390 & 57.95 & 23.26 & 0.67511 & $1 / 32$ & 0.1915 \\
\hline $2 \mathrm{H}-1,77$ & 6.73 & 0.00 & 0.96 & 520 & 59.91 & 23.29 & 0.5859 & $1 / 32$ & 0.1988 \\
\hline $2 \mathrm{H}-1,92$ & 3.46 & 0.00 & 0.96 & 520 & 73.34 & 23.26 & 0.6182 & $1 / 32$ & 0.1754 \\
\hline $2 \mathrm{H}-1,107$ & 1.77 & 0.00 & 0.00 & 283 & 75.27 & 22.80 & 0.67665 & $1 / 128$ & 0.0597 \\
\hline $2 \mathrm{H}-\mathrm{i}, 122$ & 2.17 & 0.00 & 0.27 & 369 & 75.77 & 22.29 & 0.67973 & $1 / 64$ & 0.1181 \\
\hline $2 \mathrm{H}-1,137$ & 2.14 & 0.00 & 2.14 & 281 & 84.89 & 22.29 & 0.73817 & $1 / 128$ & 0.0647 \\
\hline $2 \mathrm{H}-2,2$ & 2.54 & 0.00 & 0.85 & 354 & 76.29 & 22.29 & 0.72587 & $1 / 128$ & 0.0642 \\
\hline $2 \mathrm{H}-2,17$ & 1.72 & 0.00 & 0.74 & 406 & 75.46 & 22.30 & 0.6828 & $1 / 64$ & 0.1260 \\
\hline $\begin{array}{l}2 \mathrm{H}-2,30 \\
2 \mathrm{H}-2,47\end{array}$ & 1.03 & 0.00 & 0.34 & 292 & 77.25 & 22.31 & 0.68588 & $1 / 128$ & 0.0699 \\
\hline $\begin{array}{l}2 \mathrm{H}-2,47 \\
2 \mathrm{H}-2,64\end{array}$ & 2.56 & 0.00 & 0.96 & $\begin{array}{l}313 \\
281\end{array}$ & 79.24 & 42.82 & 0.67511 & $1 / 128$ & \\
\hline $\begin{array}{l}2 \mathrm{H}-2,64 \\
2 \mathrm{H}-2,77\end{array}$ & $\begin{array}{l}2.89 \\
2.09\end{array}$ & 0.00 & 0.79 & 381 & 75.30 & 42.90 & 0.67511 & $1 / 128$ & 0.0655 \\
\hline $\begin{array}{l}2 \mathrm{H}-2,77 \\
2 \mathrm{H}-2,92\end{array}$ & $\begin{array}{l}2.09 \\
0.00\end{array}$ & $\begin{array}{l}0.00 \\
0.00\end{array}$ & 0.00 & $\begin{array}{l}287 \\
308\end{array}$ & 76.74 & 34.64 & 0.65358 & $1 / 128$ & 0.0614 \\
\hline $\begin{array}{l}2 \mathrm{H}-2,92 \\
2 \mathrm{H}-2,107\end{array}$ & $\begin{array}{l}0.00 \\
3.68\end{array}$ & 0.00 & 0.00 & $\begin{array}{l}308 \\
353\end{array}$ & $\begin{array}{l}85.08 \\
61.82\end{array}$ & $\begin{array}{l}34.56 \\
34.64\end{array}$ & $\begin{array}{l}0.55053 \\
0.47516\end{array}$ & $3 / 256$ & 0.0715 \\
\hline $2 \mathrm{H}-2,122$ & 2.55 & 0.00 & 0.32 & 314 & $\begin{array}{l}0.82 \\
46.45\end{array}$ & 2016 & 0.479 & $1 / 32$ & 0.3911 \\
\hline $2 \mathrm{H}-2,137$ & 0.49 & 0.00 & 0.00 & 407 & 51.78 & 20.13 & 0.395513 & $\begin{array}{l}1 / 10 \\
3 / 128\end{array}$ & 0.1870 \\
\hline $2 \mathrm{H}-3,2$ & 3.67 & 0.00 & 0.00 & 300 & 53.76 & 20.16 & 0.05312 & $3 / 128$ & 0.2122 \\
\hline $2 \mathrm{H}-3,17$ & 1.82 & 0.00 & 0.00 & 384 & 56.89 & 20.16 & 0.00897 & $3 / 128$ & 0.1986 \\
\hline $2 \mathrm{H}-3,30$ & 3.17 & 0.00 & 0.53 & 379 & 60.16 & 24.53 & 0.61051 & $1 / 64$ & 0.1272 \\
\hline $2 \mathrm{H}-3,47$ & 2.40 & 0.00 & 0.00 & 334 & 61.40 & 31.32 & 0.62897 & $1 / 32$ & 0.2441 \\
\hline $2 \mathrm{H}-3,62$ & 2.95 & 0.00 & 0.29 & 339 & 68.62 & 31.38 & 0.62589 & $1 / 64$ & 0.1354 \\
\hline $2 \mathrm{H}-3,77$ & 1.06 & 0.00 & 0.35 & 283 & 74.87 & 31.32 & 0.61666 & $3 / 256$ & 0.0713 \\
\hline $2 \mathrm{H}-3,92$ & 2.34 & 0.00 & 1.00 & 299 & 85.67 & 31.32 & 0.57052 & $1 / 128$ & 0.0648 \\
\hline $2 \mathrm{H}-3,107$ & 2.10 & 0.00 & 0.30 & 333 & 81.62 & 31.38 & 0.57206 & $1 / 256$ & 0.0312 \\
\hline $2 \mathrm{H}-3,122$ & 2.13 & 0.00 & 0.61 & 329 & 79.47 & 31.32 & 0.59975 & $1 / 256$ & 0.0356 \\
\hline 137 & 3.54 & 0.00 & 0.00 & 339 & 76.87 & 31.38 & 0.572 & $1 / 256$ & 0.0 \\
\hline & 3.53 & 0.00 & 0.0 & 25 & 85. & 31.32 & 0.52 & $3 / 512$ & \\
\hline $2 \mathrm{H}-$ & 3.30 & 0.0 & 0. & 30 & & 41.67 & 0.47 & 3256 & \\
\hline $2 \mathrm{H}-4,32$ & 4.32 & 0.00 & 0.33 & 301 & 73.24 & 41.67 & 0.52438 & $1 / 64$ & 0.1059 \\
\hline & & & & & & lic & **** & & \\
\hline $\begin{array}{l}2 \mathrm{H}-6,107 \\
2 \mathrm{H}-6,122\end{array}$ & $\begin{array}{r}5.50 \\
4.64\end{array}$ & 2.27 & 0.97 & $\begin{array}{l}309 \\
366\end{array}$ & 69.28 & & 0.51361 & $3 / 256$ & 0.0899 \\
\hline $\begin{array}{l}2 \mathrm{H}-6,6,22 \\
2 \mathrm{H}-6,137\end{array}$ & $\begin{array}{l}4.64 \\
4.94\end{array}$ & $\begin{array}{l}2.19 \\
2.16\end{array}$ & 0.5 & $\begin{array}{l}366 \\
324\end{array}$ & $\begin{array}{l}72.33 \\
75.52\end{array}$ & $\begin{array}{l}27.78 \\
27.78\end{array}$ & $\begin{array}{l}0.49823 \\
0.47054\end{array}$ & $1 / 128$ & \\
\hline $2 \mathrm{H}-7,2$ & 1.78 & 2.07 & 1.48 & 338 & 83.87 & 23.33 & $\begin{array}{l}0.47 \\
0.49\end{array}$ & $1 / 32$ & \\
\hline $2 \mathrm{H}-7,17$ & 3.10 & 3.99 & 1.11 & 451 & 76. & 23. & 0.50 & $3 / 128$ & 0.1 \\
\hline $2 \mathrm{H}-7,30$ & 1.76 & 2.42 & 0.44 & 455 & 70.87 & 26.11 & 0.49515 & $3 / 256$ & 0.0870 \\
\hline 138-847D- & & & & & & & & & \\
\hline & 3.87 & 2.98 & 0.30 & 336 & 68.43 & 26.09 & 0.52745 & $3 / 256$ & 0.0760 \\
\hline & 3.31 & 0.99 & 1.32 & 30 & & 26 & 0.51 & $3 / 256$ & \\
\hline $\begin{array}{l}3 \mathrm{H}-3,92 \\
3 \mathrm{H}-3,107\end{array}$ & $\begin{array}{l}1.06 \\
3.32\end{array}$ & $\begin{array}{l}2.13 \\
0.55\end{array}$ & $\begin{array}{l}1.06 \\
1.66\end{array}$ & $\begin{array}{l}282 \\
361\end{array}$ & $\begin{array}{l}75.40 \\
80.94\end{array}$ & $\begin{array}{l}28.20 \\
28.20\end{array}$ & $\begin{array}{l}0.50131 \\
0.46439\end{array}$ & $\begin{array}{l}1 / 64 \\
1 / 64\end{array}$ & $\begin{array}{l}0.0997 \\
0.0996\end{array}$ \\
\hline $3 \mathrm{H}-3,122$ & 4.73 & 0.00 & 0.8 & $\begin{array}{l}301 \\
338\end{array}$ & 80. & $\begin{array}{l}28.14 \\
28.14\end{array}$ & $\begin{array}{l}0.46 \\
0.41\end{array}$ & $\begin{array}{l}1 / 74 \\
1 / 32\end{array}$ & \\
\hline $3 \mathrm{H}-3,137$ & 3.34 & 0.29 & 0.00 & 350 & 76.92 & 28.17 & 0.39518 & $3 / 128$ & 0.1228 \\
\hline & & & & & & & & & \\
\hline $3 \mathrm{H}-1,17$ & & 0.00 & & & & & & & \\
\hline .32 & & 0.0 & & 32 & 72 & & & 15 & 0.1 \\
\hline $\begin{array}{l}47 \\
62\end{array}$ & 7.89 & 0.00 & 1.26 & 317 & 42.66 & 30.00 & 0.47 & $1 / 1$ & \\
\hline & 8.26 & 0.00 & 0.85 & 351 & 54.50 & 30.00 & 0.51207 & $1 / 32$ & 0.1969 \\
\hline 1,77 & 8.96 & 0.72 & 1.43 & 279 & 68.72 & 30.00 & 0.54591 & $1 / 64$ & 0.1029 \\
\hline $\begin{array}{l}3 \mathrm{H}-1,92 \\
3 \mathrm{H}-1,107\end{array}$ & 2.57 & 0.00 & 1.14 & 350 & 64.22 & 31.51 & 0.60897 & i/t & \\
\hline $3 \mathrm{H}-1,107$ & 3.86 & 0.00 & 0. & 389 & 67.07 & 31.58 & 0.56 & $1 / 6$ & \\
\hline $\begin{array}{l}3 \mathrm{H}-1,122 \\
3 \mathrm{H}-1,137\end{array}$ & 2.56 & 1.60 & 1.60 & 313 & 68.49 & 31.51 & 0.59 & $3 / 256$ & 0.0 \\
\hline $3 \mathrm{H}-1,137$ & 0.32 & 0.00 & 0.63 & $\begin{array}{l}315 \\
305\end{array}$ & 65.22 & 31.58 & 0.54745 & $1 / 128$ & 0.0617 \\
\hline $3 \mathrm{H}-2,2$ & $\begin{array}{l}3.61 \\
3.87\end{array}$ & 0.6 & 0.5 & $\begin{array}{l}305 \\
362\end{array}$ & 63.81 & 31.51 & 0.53514 & $3 / 256$ & 0.0843 \\
\hline $\begin{array}{l}3 \mathrm{H}-2,17 \\
3 \mathrm{H}-2\end{array}$ & 3.87 & 0.00 & 1.66 & 362 & $\begin{array}{l}66.79 \\
\varsigma 8\end{array}$ & 31.55 & 0.49208 & $1 / 128$ & 0.0573 \\
\hline $3 \mathrm{H}-2,65$ & $\begin{array}{l}2.04 \\
4.00\end{array}$ & $\begin{array}{l}0.00 \\
0.36\end{array}$ & 0.36 & $\begin{array}{l}441 \\
275\end{array}$ & $\begin{array}{l}58.18 \\
49.73\end{array}$ & $\begin{array}{l}31.54 \\
29.34\end{array}$ & $\begin{array}{l}0.48285 \\
0.38595\end{array}$ & $\begin{array}{l}1 / 64 \\
1 / 12\end{array}$ & $\begin{array}{l}0.0937 \\
0.1684\end{array}$ \\
\hline $3 \mathrm{H}-2,107$ & 4.98 & 0.25 & 0.25 & 402 & 44.22 & 30.20 & 0.40748 & $1 / 16$ & 0.3692 \\
\hline
\end{tabular}

Note: Foraminiferal codes are listed in Table 2. 